\author{
JAN KĘSIK \\ Uniwersytet Wrocławski
}

\title{
UDZIAE WOJSKA W AKCJI \\ REWINDYKACYJNO-POLONIZACYJNEJ WE WSCHODNICH I POŁUDNIOWYCH POWIATACH WOJEWÓDZTWA LUBELSKIEGO W LATACH 1937-1939
}

Akcja rewindykacyjno-polonizacyjna na Chełmszczyźnie i Podlasiu Południowym mieściła się w przyjętym przez władze państwowe w drugiej połowie lat trzydziestych programie polityki narodowościowej wobec mniejszości ukraińskiej ${ }^{1}$. Pierwszoplanową rolę w konstruowaniu jego założeń, a później realizacji, odegrały czynniki wojskowe. Jednym z jej podstawowych celów była marginalizacja lub całkowita likwidacja problemów wynikających z aktywności politycznej mniejszości ukraińskiej we wschodnich i południowych powiatach województwa lubelskiego. Wojsko dysponowało bogatym instrumentarium pozwalającym na kreowanie działań w tym zakresie. W przypadku Lubelszczyzny i Wołynia kluczową rolę odegrał powołany w grudniu 1936 r. Komitet Koordynacyjny przy Dowództwie Okręgu Korpusu II w Lublinie oraz struktury jemu podległe, czyli komitety niższego szczebla (powiatowe i gminne), a także lokalne oddziały Towarzystwa Rozwoju Ziem Wschodnich.

${ }^{1}$ Szerzej na ten temat: P. Stawecki, Następcy Komendanta. Wojsko a polityka wewnętrzna Drugiej Rzeczypospolitej w latach 1935-1939, Warszawa 1969; A. Chojnowski, Koncepcje polityki narodowościowej rząów polskich 1921-1939, Wrocław 1979; M. Papierzyńska-Turek, Między tradycja a rzeczywistością. Państwo wobec prawosławia 1918-1939, Warszawa 1989. Z nowszych prac należy wymienić publikację Grzegorza Kuprianowicza, 1938. Akcja burzenia cerkwi prawosławnych na Chełmszczyźnie i Południowym Podlasiu, Chełm 2008, zbiór materiałów pokonferencyjnych pod jego redakcją, przygotowanych w związku z 70. rocznicą akcji niszczenia cerkwi prawosławnych na Chełmszczyźnie, Akcja burzenia cerkwi prawosławnych na Chełmszczyźnie i Południowym Podlasiu w 1938 roku - uwarunkowania, przebieg, konsekwencje, red. G. Kuprianowicz, Chełm 2009, oraz monografię ks. Krzysztofa Grzesiaka, Diecezja lubelska wobec prawosławia w latach 1918-1939, Lublin 2010. 
Komitet Koordynacyjny przy DOK II powstał, aby „wzmóc, uporządkować i skoordynować, a przez to skuteczniejszymi uczynić wysiłki społeczeństwa zmierzające do podniesienia potęgi militarnej i gotowości wojennej Państwa"2. W taki sposób jego cele definiował przyjęty w maju 1937 r. regulamin. Od początku władze wojskowe w tym okręgu na pierwszym miejscu stawiały sprawę konsolidacji społeczeństwa polskiego wokół kluczowej dla wschodniej Lubelszczyzny akcji rewindykacyjno-polonizacyjnej. Miało się to dokonać w myśl hasła-postulatu, ,by wszystko, co polskie - do Polski powróciło"3. Przygotowania rozłożone były w czasie. W połowie lipca $1937 \mathrm{r}$. opracowano wstępne wytyczne dla planowanych działań ${ }^{4}$. Równocześnie trwały prace nad tworzeniem i rozbudową struktur lokalnych, które miały przeprowadzić całe przedsięwzięcie w terenie. Na tym etapie mocno akcentowano potrzebę odzyskania „zruszczonych” Polaków dla państwa, a nie dla Kościoła katolickiego ${ }^{5}$.

Wstępne wytyczne zawierały jasno zdefiniowany wymóg, aby przygotowywana akcja odbyła się z poszanowaniem istniejącego prawa: „Pamiętać należy, że każdy obywatel, który prawa Rzeczypospolitej Polskiej szanuje i zachowuje - nie tylko ma prawo swobody używania ojczystej mowy, wolności wyznania i kulturalnego rozwoju, lecz również powinien spotkać się z naszą życzliwością"6. Praktyka jednak często do tego nie przystawała. Realizacja wyodrębnionej w planach Komitetu Koordynacyjnego DOK II akcji rewindykacyjno-polonizacyjnej na Chełmszczyźnie i Podlasiu Południowym powierzona została stacjonującej na tym terenie 3 Dywizji Piechoty Legionów. Dowodził nią gen. Brunon Olbrycht, a od 21 maja 1938 r. płk Marian Turkowski.

W końcu października 1937 r., zanim jeszcze sformułowane zostały ostateczne cele całego przedsięwzięcia, zaakceptowane przez dowódcę OK II i uzgodnione z wojewodą lubelskim, kuratorium oświaty oraz miejscowym biskupem katolickim, gen. Olbrycht wydał samodzielnie zarządzenie w tej sprawie. Wysłane zostało ono do podległych mu dowódców pułków: płk. Romualda Niementowskiego, dowódcy 2 Pułku Strzelców Konnych w Hrubieszowie, ppłk. Władysława Muzyki, dowódcy 7 Pułku

${ }^{2}$ CAW, 3 Dywizja Piechoty Legionów (dalej: 3 DPL), sygn. I,313,3,2, Regulamin Komitetu Koordynacyjnego przy Dowództwie Okręgu Korpusu (dalej: DOK) II, 28 V 1937, b.pag.

${ }^{3}$ CAW, Wojskowy Instytut Naukowo-Oświatowy (dalej: WINO), sygn. I,300,68,26, Uchwała Komitetu Koordynacyjnego przy DOK II, Lublin, 4 VI 1937, b.pag.

${ }^{4}$ CAW, 3 DPL, sygn. I,313,3,2, Komitet Koordynacyjny przy DOK II. Wytyczne dla kierowników akcji KK w terenie, 17 VII 1937,b.pag.

${ }^{5}$ Ibidem.

${ }^{6}$ CAW, WINO, sygn. I,300,68,26, Uchwała Komitetu Koordynacyjnego przy DOK II, Lublin, 4 VI 1937, b.pag. 
Piechoty Legionów w Chełmie, ppłk. Stanisława Sosabowskiego, dowódcy 9 Pułku Piechoty Legionów w Zamościu, oraz mjr. Edwarda Wunderlicha, komendanta obwodowego Przysposobienia Wojskowego w Chełmie. Oczywiście o sprawie poinformowany został również dowódca OK gen. Mieczysław Smorawiński

Zarządzenie gen. Olbrychta z 26 października 1937 r. było już niejednokrotnie przedmiotem analiz polskiej historiografii. Po raz pierwszy zajął się nim szerzej Piotr Stawecki w książce wydanej w 1969 r. ${ }^{8}$, po nim zaś inni ${ }^{9}$. Stawecki i pozostali badacze koncentrowali się bardziej na analizie zapowiedzi represywnych działań wojska i administracji cywilnej, skierowanych wobec mniejszości ukraińskiej na Lubelszczyźnie, skądinąd w większości zrealizowanych w nieodległej przyszłości, niż na kontekstach z tym związanych. W ten sposób umyka kwestia podobnych, wcześniejszych „eksperymentów religijno-narodowościowych” na tym terenie. Analizując dokumenty dotyczące akcji polonizacyjno-rewindykacyjnej, nie sposób abstrahować też od takich faktów, jak pogarszające się położenie międzynarodowe Polski oraz lawinowy wzrost nastrojów irredentystycznych wśród Ukraińców zamieszkujących II Rzeczpospolitą, także na Lubelszczyźnie. Trzeba też dostrzec - sygnalizowane przez Grzegorza Jacka Pelicę, autora monografii Kościoła prawosławnego w województwie lubelskim - zjawisko postępującej ukrainizacji prawosławia we wschodnich i południowych powiatach tego regionu ${ }^{10}$. Dopiero uwzględnienie tych aspektów pozwala pełniej zrozumieć inicjatywy sił zbrojnych z lat 1937-1939.

Władze wojskowe przyjęły założenie, że „wszyscy prawosławni Chełmszczyzny są zruszczonymi Polakami"11. Sprawa wymaga szerszego komentarza. Trzeba pamiętać, że w 1875 r., czyli sześćdziesiąt lat wcześniej, co mniej więcej odpowiada dwóm-trzem pokoleniom, władze carskie doprowadziły tu do całkowitej likwidacji Kościoła grekokatolickiego. Towarzyszyło temu bezwzględne odbieranie majątku parafialnego unitów, bez żadnego baczenia na ich uczucia religijne. Represje spotkały również wyznawców Kościoła rzymskokatolickiego. Mimo oporu wiernych wiele obiektów sakralnych należących do obu Kościołów zostało w tym czasie zniszczonych. Pozostała własność unitów oraz świątynie

${ }^{7}$ CAW,3 DPL,sygn.I,313,3,2,Akcja polonizacyjna na Chełmszczyźnie, 26 X 1937,b.pag.

${ }^{8}$ P. Stawecki, op. cit.

${ }^{9}$ M.Papierzyńska-Turek, op. cit., s. 269; A. Chojnowski, op. cit., s. 230-231.

10 G.J. Pelica, Kościół prawosławny w województwie lubelskim (1918-1939), Lublin 2007, s. 271.

${ }^{11}$ CAW,3 DPL,sygn.I,313,3,2,Akcja polonizacyjna na Chełmszczyźnie, 26 X 1937,b.pag. 
odebrane katolikom znalazły się w posiadaniu Cerkwi prawosławnej ${ }^{12}$. Likwidacja Kościoła grekokatolickiego tłumaczona była też potrzebą powrotu do wiary ojców po prześladowaniach będących następstwem jakoby narzuconej prawosławnym unii brzeskiej z 1596 r. Z drugiej jednak strony twierdzenie, iż zmuszeni do przejścia na prawosławie unici byli zruszczonymi Polakami, ma też słabe oparcie w rzeczywistości. Z pewnością w zdecydowanej większości należeli oni do etnosu niepolskiego.

Tak czy inaczej, „nawracanie” na prawosławie siłą nie mogło przynieść trwałych efektów. Potwierdziły to wydarzenia, które miały miejsce 40 lat później, z chwilą ukazania się tzw. ukazu tolerancyjnego (1905). Znosił on prawo zakazujące poddanym rosyjskim zrywania z prawosławiem. Z tym jednak, że konwertyci zobowiązani byli do pozostawienia w Cerkwi całego majątku parafialnego. Mimo niekorzystnych w tym względzie zapisów ustawowych wielu byłych unitów lub ich potomków zdecydowało się na powrót/przejście do wiary katolickiej. Szacuje się, że w latach 1905-1909 na katolicyzm na Chełmszczyźnie i Podlasiu przeszło od około 58 tys. do przeszło 170 tys. dotychczasowych wyznawców prawosławia. Według tych samych danych przy Cerkwi pozostać miało tu ponad 230 tys. wiernych ${ }^{13}$.

A zatem akcja rewindykacyjno-polonizacyjna na Chełmszczyźnie i Podlasiu Południowym z lat 1937-1939 nie była pierwszym tego rodzaju „eksperymentem” z zakresu polityki wyznaniowo-narodowościowej.Już wcześniej, przynajmniej dwukrotnie, naturalne procesy zakorzeniania w sferze wiary zakłócane były tu w wyniku decyzji politycznych. W konsekwencji występowały na tym terenie zarówno społeczności mocno przywiązane do Cerkwi prawosławnej i jej tradycji, jak i takie, dla których związek z tym wyznaniem był bardziej labilny. W latach trzydziestych przekładało się to również na stosunek do kwestii narodowej. Co więcej, analizowana akcja nie była też „eksperymentem” ostatnim. W zjawiska te wpisuje się również głośna pacyfikacja Zamojszczyzny przeprowadzona przez niemieckiego okupanta w latach 1942-1943 i łącząca się z tym polityka wspierania prawosławia kosztem ludności polskiej wyznania rzymskokatolickiego.

Władze wojskowe miały pełną świadomość, że przyjęty program polonizacyjny będzie musiał mieć charakter długofalowy, obliczony przynajmniej na dwa pokolenia. Wytyczne gen. Olbrychta dzieliły wyznawców prawosławia na Chełmszczyźnie na trzy kategorie. Do pierwszej zaliczał on

${ }^{12}$ J. Kania, Rozbiórki cerkwi na Lubelszczyźnie w roku 1938 a stanowisko biskupa Fulmana, w: Chrześcijański Wschód a kultura polska, red. R. Łużny, Lublin 1989, s. 31-52.

${ }^{13}$ G.J. Pelica, op. cit., s. 26. 
osoby najbardziej chwiejne pod względem wyznaniowym, które będzie można stosunkowo łatwo zachęcić do przejścia na obrządek rzymskokatolicki. Zalecał, aby poprzez perswazję przekonać ich, że „przodkowie przyjęli prawosławie pod przymusem i że oni, mając obecnie swobodę wyboru religii, winni powrócić na łono macierzystego kościoła" ${ }^{14}$. Druga kategoria to ci, którzy byli silnie przywiązani do prawosławia, ale nie mieli skrystalizowanej ukraińskiej świadomości narodowej. Wobec nich dowódca stacjonującej w Zamościu dywizji piechoty zalecał „stosować liberalną politykę wyznaniową i unikać jakichkolwiek na tym tle zadrażnień. Musi się w nich wpoić przeświadczenie, że religia nie stanowi o przynależności narodowej i że - jak dobrymi Polakami mogą być rzymscy katolicy, czy ewangelicy, równie dobrze mogą nimi być ci prawosławni, którzy są Polakami i Polakami się czują"15. Nawet w odniesieniu do trzeciej kategorii, czyli osób deklarujących się jako Ukraińcy wyznania prawosławnego, należało „na razie przynajmniej - podchodzić bardzo ostrożnie i ograniczyć się do wyrabiania w nich lojalności państwowej, zmniejszając w terenie ich wpływ drogą rozbijania większych skupisk ludności tego typu, odgradzania ich zaporą osiedli polskich od skupień bardziej politycznie czynnych"16. Zawarte w cytowanym dokumencie propozycje działań polonizacyjnych mieściły się w granicach dopuszczalnych przez ówczesne prawo. Uwaga ta dotyczy wyłącznie projektowanych zamierzeń, a nie ewentualnej praktyki.

Tego rodzaju plan wymagał przeprowadzenia skrupulatnych prac wstępnych, które dawałyby szczegółowy obraz sytuacji wyznaniowo-narodowościowej nie tylko w poszczególnych gminach, ale nawet w konkretnych wsiach. Dowódca dywizji nakazywał, aby powoływani w powiatach kierownicy akcji polonizacyjnej przeprowadzili dokładną analizę sytuacji narodowościowej na swoim terenie. Miała ona zawierać między innymi informacje o strukturze narodowościowej i wyznaniowej poszczególnych wsi oraz granicach parafii prawosławnych. Chodziło też o ustalenie, w których miejscowościach znajdują się nieoficjalne (nieetatowe) parafie prawosławne i nieczynne cerkwie, a nawet, z jakiego materiału świątynie te zostały wykonane. Można więc domniemywać, że już wtedy wojsko brało pod uwagę możliwość ich rozbiórki lub przygotowywało taki plan. Dużą wagę przykładano do zagadnień parcelacyjnych. Kierownicy akcji kolonizacyjnej zobowiązani zostali do przeprowadzenia rozeznania, które majątki będą dzielone w najbliższym

\footnotetext{
${ }^{14}$ CAW,3 DPL, sygn.I,313,3,2,Akcja polonizacyjna na Chełmszczyźnie, 26 X 1937,b.pag.

${ }^{15}$ Ibidem.

${ }^{16}$ Ibidem.
} 
czasie. Zgodnie z zaleceniami dowódcy dywizji tego rodzaju grunty miały być rozdysponowywane tylko pomiędzy Polaków. W planach wojska chodziło o „odgrodzenie Chełmszczyzny wałem wsi polskich od Małopolski Wschodniej i Bugu oraz [--] rozsadzenie większych skupisk rusińskich osadami czysto polskimi". Na wykonanie tak rozległych zadań analitycznych gen. Olbrycht pozostawiał swoim podwładnym niewiele czasu. Raporty w tej sprawie gotowe miały być do końca listopada $1937 \mathrm{r} .{ }^{17}$

Po przeprowadzeniu zalecanych analiz należało niezwłocznie przystąpić do przygotowania miejscowych programów działania, które obejmować miały: dywersyfikacje wsi ze względu na nastawienie polityczne mieszkającej w nich ludności prawosławnej, projekty parcelacyjne, plany rozbudowy parafii katolickich z uwzględnieniem możliwości zastąpienia nimi istniejących parafii prawosławnych, plany rozbudowy szkół oraz projekty likwidacji nieczynnych cerkwi. To ostatnie zadanie miało być środkiem prowadzącym do ograniczenia wpływu i zasięgu prawosławia. Na podstawie sformułowanych w ten sposób programów działania komendanci akcji polonizacyjno-rewindykacyjnej w powiatach otrzymali zadanie stworzenia instrukcji postępowania w tym zakresie dla władz lokalnych, administracji szkolnej i skarbowej, duchowieństwa oraz wojska. Programy działania wraz z wytycznymi dla wspomnianych instytucji gotowe miały być najpóźniej w połowie lutego 1938 r., tak aby od wiosny przystąpić do planowej akcji polonizacji Chełmszczyzny ${ }^{18}$.

Zanim przygotowane zostały lokalne programy działania, 20 stycznia 1938 r. gen. Olbrycht w wysłanej podwładnym instrukcji doprecyzował zasady prowadzenia działań polonizacyjno-rewindykacyjnych. W ramach lokalnych struktur Komitetów Koordynacyjnych DOK II powołani zostać mieli powiatowi kierownicy akcji. Byli nimi zazwyczaj oficerowie jednostek stacjonujących na danym terenie, rzadziej zamieszkali w okolicy oficerowie rezerwy. Dowódca dywizji podkreślał konieczność wciągnięcia w całe przedsięwzięcie nie tylko struktur administracji cywilnej, ale również lokalnej społeczności. Zobowiązywał, aby Komitety Koordynacyjne konsolidowały polskie organizacje społeczne wokół planowanych działań polonizacyjnych. Szczególną rolę do odegrania miało TRZW, traktowane jako narzędzie realizacji planów wojska ${ }^{19}$.

Kluczowym dokumentem pozwalającym na prześledzenie procesu radykalizacji planów polonizacyjnych we wschodnich i południowych powiatach województwa lubelskiego wydaje się pismo zatytułowane „Pod-

\footnotetext{
${ }^{17}$ Ibidem.

${ }^{18}$ Ibidem.

${ }^{19}$ G. Kuprianowicz, op. cit., s. 35.
} 
stawowe wytyczne do polonizacji Chełmszczyzny" ${ }^{20}$. Niestety jest ono niedatowane i niepodpisane, ale w moim przekonaniu powstało później niż omawiany wcześniej dokument z końca października 1937 r., lecz jeszcze przed rozpoczęciem samego niszczenia cerkwi, czyli przed połową maja następnego roku. Wiemy jedynie, że pochodzi z zespołu akt 3 DPL. Zawiera o wiele bardziej zdecydowane i represywne propozycje polonizacji Nadbuża, chociaż w dużych fragmentach powtarza też pomysły zawarte w omawianych wcześniej pismach gen. Olbrychta z końca października 1937 i stycznia następnego roku. Nowe wytyczne jeszcze raz podkreślały konieczność konsolidacji społeczeństwa polskiego wokół misji polonizacji Chełmszczyzny oraz swoiście rozumianego ekskluzywizmu narodowego. Czytamy w nich: „przenoszenie animozji politycznych na teren akcji polonizacyjnej jest zaprzepaszczaniem samej akcji. Należy podkreślać, że panem na tej ziemi jest ten, kto o tę ziemię walczył, o tę ziemię się modlił i za polskość tej ziemi cierpiał" ${ }^{21}$. W ocenie czynników wojskowych nawet aktywność gospodarcza mniejszości ukraińskiej na Chełmszczyźnie stawała się groźniejsza z punktu widzenia interesów państwa aniżeli żydowska. W związku z tym zalecano: „lepiej nie rugować Żyda [pisownia współczesna - J.K.] z danej placówki, gdy ta placówka objęta ma być nie przez Polaka, a przez uświadomionego nacjonalistę ruskiego"22.

Zdaniem władz wojskowych, na Lubelszczyźnie prawosławie było głównym rozsadnikiem tendencji ukrainizacyjnych. Stąd każda polityka narodowościowa na tym terenie z natury rzeczy musiała być skoncentrowana na kwestiach wyznaniowych. Tej sprawie omawiany dokument poświęcał najwięcej miejsca. Nowe wytyczne wyraźnie zaostrzały metody postępowania. Od duchownych prawosławnych wymagano całkowitego podporządkowania się akcji polonizacyjnej i pozostawania pod stałą obserwacją władz oraz społeczeństwa polskiego. Jakiekolwiek podejrzenia o wspieranie ukraińskiej działalności narodowej miały być zwalczane „wszelkimi sposobami”. Ważną rolę wyznaczono duchowieństwu katolickiemu. Winno ono, między innymi, wciągać na lekcje religii rzymskokatolickiej dzieci prawosławne. Sposobem na pozyskanie ortodoksów miało być też zwalnianie zmieniających wyznanie z opłat z tytułu chrztu, ślubu czy pogrzebu lub ich obniżanie. Oczywiście wytyczne powtarzały postulaty likwidacji nieetatowych parafii prawosławnych oraz nieczynnych

${ }^{20}$ CAW, 3 DPL, sygn. I,313,3,2, Podstawowe wytyczne do polonizacji Chełmszczyzny, b.d., b.pag.

${ }^{21}$ Ibidem.

${ }^{22}$ Ibidem. 
cerkwi, ale jeszcze bez sprecyzowania ich liczby. Czynnikom wojskowym szczególnie zależało, aby tego rodzaju działania miały przynajmniej pozory wsparcia ze strony miejscowego społeczeństwa polskiego. W związku z tym instruowano, żeby

a) organizować akcję społeczną przeciw kazaniom prawosławnym i nauce religii oraz posługiwaniu się przez popów innym językiem jak język polski. Powinność tę dokonywać w formie publicznych zbiorowych wystąpień i deklaracji.b) Na terenach o obojętności religijnej pobierać [„popierać”J.K.] uchwały o likwidacji cerkwi nieczynnych.c) Zwalczać małżeństwa mieszane, o ile nie są zawierane w kościele rzym.-kat. ${ }^{23}$

Znalazł się również postulat rugowania z Chełmszczyzny nauczycieli „narodowo niepewnych".

Po kilku miesiącach przygotowań, z początkiem marca 1938 r., program polonizacyjno-rewindykacyjny na Chełmszczyźnie wszedł w fazę praktycznej realizacji. Kilka kluczowych decyzji z nim związanych zapadło 8 marca. Tego właśnie dnia dowódca 3 DPL wysłał do kierowników akcji polonizacyjnej w terenie pismo z poleceniem, aby „w sposób zdecydowany i energiczny" przystąpić do działań propagandowych. Używając poetyki wojskowej, miało to być coś na kształt przygotowania artyleryjskiego przed zasadniczą ofensywą, czyli praktycznymi działaniami likwidacyjnymi. Nakazywał inicjowanie zebrań organizacji społecznych, kombatanckich, paramilitarnych oraz ugrupowań politycznych, na których podejmowane miały być rezolucje domagające się od władz państwowych reakcji na zaangażowanie duchowieństwa prawosławnego w ukraińską działalność narodową. Uchwały należało wysyłać do Ministerstwa Spraw Wewnętrznych oraz Ministerstwa Spraw Wojskowych. Aby uniknąć jakiejkolwiek dowolności w formułowaniu ich tekstu, do korespondencji dołączona została wzorcowa rezolucja uchwalona już wcześniej w Tomaszowie Lubelskim, z podkreślonymi fragmentami, które należało skopiować. Jednocześnie gen. Olbrycht instruował - „w żadnym wypadku nie wolno występować przeciw prawosławiu, lecz tylko przeciwko tym, którzy prawosławie chcą używać dla prowadzenia agitacji rusko-ukraińskiej”. Wraz z rezolucjami dopuszczono wysyłanie listy z nazwiskami popów zaangażowanych w działalność proukraińską. Zgodnie z programem Komitetów Koordynacyjnych zebrania miały być wykorzystane również do „rozagitowania i zespolenia wszystkich Polaków w akcji przeciw wrogim czynnikom" ${ }^{24}$. Dowódca dywizji, będący zarazem

${ }^{23}$ Ibidem.

${ }^{24}$ CAW, 3 DPL, sygn. I,313,3,2, Pismo gen. B. Olbrychta do kierowników akcji, 8 III 1938, b.pag. 
kierownikiem akcji polonizacyjnej na całą Chełmszczyznę, z wyjątkową precyzją instruował nie tylko w sprawie treści rezolucji, ale również scenariusza i terminów zebrań. Odbywać się miały dokładnie pomiędzy 13 marca a 15 kwietnia 1938 r. Każde należało rozpocząć od odśpiewania hymnu narodowego, a zakończyć pierwszą zwrotką Roty.Zebraniom towarzyszyć też powinny akcje wiecowe we wszystkich większych osiedlach na tym terenie. Poza tym generał polecił, aby do 15 kwietnia z każdego powiatu wysłać do warszawskich gazet i „Kuriera Krakowskiego” po 5 artykułów - miały one „zaalarmować Warszawę, oraz obudzić społeczeństwo i odpowiednie czynniki centralne"25.

Sam jeszcze tego samego dnia wysłał do MSWojsk dwa inne pisma związane z działaniami polonizacyjno-rewindykacyjnymi we wschodnich i południowych powiatach woj. lubelskiego. Adresatem pierwszego był ppłk Stanisław Sadowski z Wydziału Bezpieczeństwa Departamentu Dowodzenia Ogólnego MSWojsk. Zawierało ono prośbę o wsparcie w Ministerstwie Wyznań Religijnych i Oświecenia Publicznego oraz MSW żądania starosty zamojskiego wysiedlenia z terenu powiatu prawosławnego mnicha, który rzekomo podejmował aktywną działalność narodowościową ${ }^{26}$.

Większą wagę gatunkową miało drugie pismo, skierowane bezpośrednio na ręce ministra spraw wojskowych gen. Tadeusza Kasprzyckiego. Dowódca 3 DP stanowczo domagał się w nim większego wsparcia ze strony resortu obrony dla działań przygotowanych przez Komitet Koordynacyjny przy DOK II. Wychodząc z założenia, że Kościół prawosławny na Chełmszczyźnie jest instytucją „rusyfikacyjną”, gen. Olbrycht sformułował jedenaście postulatów, od których spełnienia zależeć miało to, ,,czy wschodnie części województwa lubelskiego zostaną polskie, czy też ukraińskie"27. Wspomniane punkty w zasadzie powtarzały propozycje zawarte w wytycznych dla polonizacji Chełmszczyzny, niemniej jednak pojawiły się też nowe akcenty. Przede wszystkim generał postulował natychmiastowe rozebranie lub przekazanie katolikom 54 zamkniętych dotąd cerkwi. Pomysł rozbiórki nieczynnych cerkwi oczywiście pojawiał się już wcześniej, ale dopiero od tego momentu zaczęto mówić o konkretnych liczbach świątyń do likwidacji. Równocześnie powołanych miało zostać 38 nowych parafii rzymskokatolickich oraz 3 nowe klasztory: reformatów w Chełmie, franciszkanów w Soli i jedno zgromadzenie w powiecie hrubieszowskim. Poza tym generał oczekiwał wsparcia ze strony swojego resortu dla pomysłu

${ }^{25}$ Ibidem.

${ }^{26}$ Ibidem, Pismo gen. B. Olbrychta do ppłk. S. Sadowskiego, 8 III 1938, b.pag.

${ }^{27}$ Ibidem, Pismo dow. 3 DPL do ministra spraw wojskowych w sprawie akcji polonizacyjnej na b. Chełmszczyźnie, 8 III 1938, b.pag. 
przeniesienia z Radomia do Chełma Dyrekcji Kolejowej, co pozwoliłoby na wzmocnienie miejscowego środowiska polskiego ${ }^{28}$.

Wybór daty rozpoczęcia zmasowanej aktywności propagandowej poprzedzającej niszczenie nieczynnych cerkwi na Chełmszczyźnie i Podlasiu oraz termin samych rozbiórek nie były przypadkowe. Miały bezpośredni związek z dobiegającymi końca rozmowami na temat statusu prawnego Cerkwi w Polsce. Toczyły się one od wielu lat pomiędzy rządem a władzami Kościoła prawosławnego ${ }^{29}$. Metropolita Dionizy wspierał, a nawet inspirował działania, których celem było tworzenie - wbrew miejscowym władzom - nowych, niezatwierdzonych przez państwo parafii prawosławnych (nieetatowych). Liczył, że tego rodzaju taktyka faktów dokonanych przyniesie efekt w postaci zalegalizowania nowych placówek w finalizowanej właśnie umowie. Na początku 1938 r. na Chełmszczyźnie działało 55 nieetatowych parafii prawosławnych $\mathrm{i}$ ich filii ${ }^{30}$. W rozmowach w ramach mieszanej komisji rządowo-cerkiewnej uzgodniono legalizację większości z nich, czemu zdecydowanie przeciwne były władze wojewódzkie oraz wojskowe, ponieważ w ich ocenie zagrażało to planom spolonizowania wschodnich powiatów Lubelszczyzny. Poza tym naruszałoby przyjętą jeszcze na początku lat dwudziestych zasadę, wedle której parafie prawosławne i katolickie miały posiadać zbliżoną liczbę wiernych. Tak więc planowana likwidacja tych obiektów miała uniemożliwić utworzenie nowych parafii prawosławnych wstępnie uzgodnionych w rozmowach pomiędzy rządem a władzami Kościoła prawosławnego.

21 maja 1938 r., mniej więcej tydzień po rozpoczęciu akcji burzenia prawosławnych obiektów sakralnych, płk Turkowski zastąpił na stanowisku dowódcy 3 DPL gen. Olbrychta, który z kolei objął po Turkowskim komendanturę Centrum Dowodzenia Piechoty w Rembertowie. Nota bene gen. Olbrycht dowodził już wcześniej Centrum w latach 1930-1936 ${ }^{31}$. Rodzi się więc pytanie, czy roszada na stanowisku dowódcy dywizji miała coś wspólnego z rozpoczętą właśnie akcją polonizacyjną. Znane autorowi materiały archiwalne nie pozwalają na odpowiedź wprost w tej sprawie.

Ostatni meldunek gen. Olbrychta dotyczący działań na Chełmszczyźnie przesłany do MSWojsk pochodził z 12 kwietnia $1938 \mathrm{r}^{32}$ Pismo to ma istotne znaczenie dla odtworzenia dalszego przebiegu i zakresu akcji po-

${ }^{28}$ Ibidem.

${ }^{29}$ Szerzej na ten temat: M. Papierzyńska-Turek, op. cit.

${ }^{30}$ K. Grzesiak, op. cit., s. 59-64.

${ }^{31}$ T. Kryska-Karski, S.Żurakowski, Generałowie Polski niepodległej, Warszawa 1991, s. 139.

32 CAW, 3 DPL, sygn. I,313,3,2, Pismo dow. 3 DPL do ministra spraw wojskowych, 12 IV 1938, b.pag. Z treści tego meldunku wynika, że od 8 marca była to jedyna korespondencja gen. Olbrychta z MSWojsk. 
lonizacyjno-rewindykacyjnej we wschodnich powiatach woj. lubelskiego. Być może pozostawało też w związku z losami generała jako dowódcy dywizji. W tym czasie działania wojska i administracji skierowane były w pierwszej kolejności na sprawę likwidacji nieetatowych parafii prawosławnych oraz eliminowanie $\mathrm{z}$ terenu duchownych łączących, zdaniem władz, działalność duszpasterską z narodową. Powodzenie projektów polonizacyjnych na Chełmszczyźnie zależało w istotnej części od zaangażowania duchowieństwa katolickiego. W ocenie generała Olbrychta nie było ono dotąd satysfakcjonujące. W związku z tym domagał się on od swoich zwierzchników interwencji u kardynała Augusta Hlonda w celu poparcia planów utworzenia na terenie wschodniej Lubelszczyzny 38 nowych etatów dla obsadzenia probostw nowo tworzonych parafii rzymskokatolickich. Równocześnie w dość ostrej formie sugerował czy wręcz pouczał, jak powinna wyglądać polityka państwa wobec Cerkwi prawosławnej w Polsce. Jego zdaniem „żaden rząd w żadnym państwie nie ścierpiałby tego stanu rzeczy, żeby jakikolwiek duchowny bez zezwolenia władz po chałupach odprawiał nabożeństwa i prowadził antypaństwową agitację" ${ }^{33}$. Irytację przełożonych mogły wywołać również żądania wyasygnowania pół miliona złotych na wsparcie planów polonizacyjnych na Chełmszczyźnie. Zaskakująca była argumentacja, zwłaszcza że jej autor wywodził się ze środowiska wojskowego. Gen. Olbrycht przekonywał, iż „suma pół miliona złotych wyznaczona na cele te czy to z funduszu dyspozycyjnego jakiegoś ministerstwa, czy to z pieniędzy FON [Fundusz Obrony Narodowej] da większe rezultaty niż kupno kilkudziesięciu karabinów maszynowych. Wyrwanie 100000 Polaków z rąk ruskich i ukraińskich przedstawia większą wartość obronną niż kilkadziesiąt karabinów maszynowych" ${ }^{34}$. Niespełna półtora miesiąca po wysłaniu tego pisma gen. Olbrycht przestał być dowódcą 3 DP w Zamościu.

Szerszego omówienia wymaga również sześć załączników dołączonych do analizowanego meldunku z 12 kwietnia 1938 r. Zawierają one precyzyjne wykazy miejscowości, w których znajdują się nieczynne obiekty sakralne, wraz z propozycjami ich zagospodarowania bądź likwidacji. Obejmują miejscowości znajdujące się na terenie pięciu powiatów: biłgorajskiego, chełmskiego, hrubieszowskiego, tomaszowskiego oraz zamojskiego, co wydaje się zrozumiałe, był to bowiem obszar działania 3 Dywizji. Załączniki pozwalają na wyrobienie sobie szerszej orientacji w sprawie planów rewindykacyjnych wojska, przynajmniej na obszarze wymienionych powiatów. Pierwszy zawierał wykaz 15 miejscowości, gdzie istniały

\footnotetext{
${ }^{33}$ Ibidem.

${ }^{34}$ Ibidem.
} 
niewykorzystywane na cele religijne kościoły katolickie. Miały one jak najszybciej zostać obsadzone przez księży i przekształcone w parafie łacińskie. 23 cerkwie zamierzano wyświęcić na kościoły lub kaplice katolickie, 55 świątyń prawosławnych przewidziano do rozbiórki ( $21 \mathrm{w}$ powiecie tomaszowskim, $12 \mathrm{w}$ chełmskim i $5 \mathrm{w}$ hrubieszowskim). W efekcie tych działań w powiecie biłgorajskim pozostawać miało 5 parafii prawosławnych (wraz z filiami), w chełmskim 9 parafii z filiami, w hrubieszowskim 14 , w tomaszowskim 7 i w zamojskim 2 parafie ${ }^{35}$. Trzeba jednak pamiętać, że w kolejnych tygodniach plany te niejednokrotnie zmieniano, a poza tym nie obejmowały one powiatów Podlasia Południowego. Tak czy inaczej, pismo gen. Olbrychta z 12 kwietnia daje wyobrażenie o zamierzeniach likwidacyjnych na Chełmszczyźnie.

Płk Turkowski 6 dni po objęciu stanowiska dowódcy dywizji przesłał do DOK II oraz kierowników akcji polonizacyjnej na podległym sobie terenie pismo, w którym zapewniał o kontynuacji zamierzeń poprzednika. Niemniej pojawiły się też nowe akcenty. Już w pierwszym punkcie pisma nowy dowódca dywizji podkreślał konieczność, zgodnie z ideą powołania Komitetów Koordynacyjnych, konsolidacji społeczeństwa polskiego i otoczenia go specjalną opieką. W przypadku wyznawców prawosławia, obok znanych już wcześniej działań rewindykacyjnych, pojawić się miały nowe metody, nie tylko o charakterze represywnym. Z jednej strony płk Turkowski stawiał na masowe konwersje, polonizację nazwisk i nazw miejscowości, z drugiej jednak proponował swego rodzaju program pozytywny, który w sposób naturalny przekonywałby ludność prawosławną do Polski. Służyć temu miał pomysł organizowania półkolonii dla biednych dzieci prawosławnych posługujących się językiem polskim, wspieranie rodzimego rzemiosła, rozbudowa sieci kas bezprocentowych czy wreszcie program rozbudowy czytelni i świetlic ludowych.

Od połowy maja 1938 r. na plan pierwszy całej akcji polonizacyjno-rewindykacyjnej wysunęła się sprawa likwidacji nieetatowych parafii prawosławnych i rozbiórek obiektów sakralnych. Kwestia ta już nieraz była przedmiotem badań historycznych, choć nie zawsze opartych na bezstronnych analizach materiałów źródłowych. Celem autora jest przede wszystkim wskazanie roli wojska w tych wydarzeniach. Nie ma bowiem racji ks. Janusz Kania, który twierdzi, iż likwidacja obiektów sakralnych na Chełmszczyźnie przeprowadzona została przez administrację lokalną bez udziału wojska ${ }^{36}$. Mało prawdopodobna wydaje się również opinia przypisywana Henrykowi Suchenek-Sucheckiemu, ówczesnemu naczel-

\footnotetext{
${ }^{35}$ Ibidem.

${ }^{36}$ J. Kania, op. cit., s. 52.
} 
nikowi Wydziału Narodowościowego MSW, jakoby akcję burzenia cerkwi na Chełmszczyźnie i Podlasiu inspirował niemiecki wywiad działający w strukturach polskiego Sztabu Głównego, przy współpracy z lubelskimi jezuitami. Wedle tej teorii chodzić miało o wywołanie fermentu narodowościowego przed zbliżającą się wojną z Polską ${ }^{37}$.

Miejscowe władze wojskowe i administracyjne na Lubelszczyźnie liczyły, że w wyniku likwidacji nieetatowych parafii prawosławnych uda się zatrzymać procesy ukrainizacji wyznawców prawosławia. Sposobem na to miała być fizyczna likwidacja lub przekazywanie na inne cele nieczynnych od 1915 r. obiektów sakralnych. Żywiły przekonanie, że pozostawienie w terenie cerkwi, kapliczek oraz domów modlitw przynosić będzie większe zagrożenia dla planów polonizacji wschodnich i południowych powiatów Lubelszczyzny niż ich usunięcie. Faktycznie lokalne spory wokół nieczynnych świątyń coraz częściej przekształcały się w konflikty o charakterze narodowym, wykorzystywane przez ukraińskie siły polityczne, dążące do zantagonizowania stosunków w Polsce. Decyzja o wyburzeniach cerkwi na Chełmszczyźnie została więc podjęta z pełną świadomością wpływu na nastroje mieszkańców, zwłaszcza ludności prawosławnej.

Rozbiórki wywoływały ogromny rezonans społeczny. Zarówno po jednej, jak i drugiej stronie komentowała je prasa. Tematyka ta była niejednokrotnie szeroko omawiana w literaturze przedmiotu, więc pominę szczegóły ${ }^{38}$. Niekiedy w publikacjach na ten temat mamy jednak do czynienia z deficytem wiedzy, a w konsekwencji narracją nie liczącą się z rzeczywistością ${ }^{39}$. W związku z tym warto, niejako na wstępie, przywołać kilka podstawowych faktów, które pozwolą lepiej osadzić omawiane zagadnienie $\mathrm{w}$ tamtych realiach historycznych. Nie ulega wątpliwości, że rozbiórki cerkwi były fragmentem szerszego planu spolonizowania wschodnich obszarów województwa lubelskiego i spacyfikowania ukraińskiego ruchu narodowego na tym terenie. Ruchu, który w wymiarze całej Polski nabierał w drugiej połowie lat trzydziestych charakteru coraz bardziej irredentystycznego, zagrażającego bezpieczeństwu wewnętrznemu. Zgodnie z planami wojska i miejscowej administracji zlikwidowane miały być tylko te obiekty, które pozostawały

${ }^{37}$ G. J. Pelica, op. cit., s. 266-267.

${ }^{38}$ M. Papierzyńska-Turek, op. cit., s. 362-367. Patrz także W. Pobóg-Malinowski, Najnowsza historia polityczna Polski, t. 2, Gdańsk 1990, s. 827-828, oraz S. Mackiewicz (Cat), Historia Polski od 11 XI 1918 do 17 IX 1939 r., Londyn 1941, s. 312.

${ }^{39}$ Ilustracją tego jest książka: M. Siwicki, Dzieje konfliktów polsko-ukraińskich,t. 3, Warszawa 1994, oraz artykuł Jurija Makara: Ю. Макар, 1938 рік - апогей трагедї Холмсько-Підляського Православ'я, w: Akcja burzenia cerkwi prawosławnych, s. 93-109. 
nieczynne lub w których działały tzw. nieetatowe parafie prawosławne, a na ich funkcjonowanie nie było przyzwolenia lokalnych władz. Na początku 1938 r. na terenie Chełmszczyzny istniało 55 parafii nieoficjalnych (nieetatowych) ${ }^{40}$. Wojsko nie przewidywało rozbiórki żadnej świątyni należącej do prawosławnej parafii etatowej, subwencjonowanej przez MWRiOP. W praktyce zasada ta została dotrzymana. Metropolita Dionizy wspierał, a nawet inspirował działania duchowieństwa, których celem było tworzenie nowych placówek duszpasterskich wykorzystujących nieczynne cerkwie. Liczył, że w umowie określającej status Cerkwi prawosławnej w Polsce parafie te staną się placówkami uznanymi przez państwo. Taką ewentualność brała pod uwagę również strona rządowa, niemniej jednak zarówno DOK II, jak i administracja wojewódzka w Lublinie były temu zdecydowanie przeciwne. Według wojska tylko fizyczna likwidacja cerkwi okazać się mogła skutecznym sposobem uniemożliwiającym usankcjonowanie rozbudowy sieci parafii prawosławnych w województwie lubelskim. W tym momencie konieczne jest jeszcze jedno wyjaśnienie, które w żaden sposób nie ma na celu usprawiedliwiania działań władz wojskowych. Zalegalizowanie ponad 50 nowych parafii na Lubelszczyźnie naruszałoby przyjętą jeszcze w pierwszej połowie lat dwudziestych zasadę, wedle której liczba parafii katolickich i prawosławnych na tym terenie miała być zbliżona ${ }^{41}$. $\mathrm{Z}$ drugiej jednak strony plany powołania 38 nowych parafii katolickich w rekoncyliowanych świątyniach, o których wspomniałem wcześniej przy okazji omawiania założeń akcji rewindykacyjno-polonizacyjnej, również naruszałyby tę zasadę ${ }^{42}$. Nie zostały one jednak zrealizowane ze względu na brak większego zainteresowania ze strony katolickich władz diecezjalnych.

Dla sprawy rozbiórek cerkwi nie ma natomiast większego znaczenia zarówno pochodzenie niszczonych obiektów sakralnych, jak i ich stan techniczny, ponieważ nie te okoliczności były faktycznym powodem ich niszczenia. W sporej części to rzeczywiście świątynie pounickie, inne zbudowano po 1875 r., były też i takie, które powstały jeszcze przed unią brzeską. Za to warto zwrócić uwagę, że co najmniej 17 rozebranych obiektów miało charakter kaplic i powstało po 1918 r. Mieściły się one najczęściej w zaadaptowanych na ten cel budynkach prywatnych, które w niczym nie przypominały swoim wyglądem typowych

${ }^{40}$ K. Grzesiak, op. cit., s. 64.

${ }^{41}$ AAN, Ministerstwo Wyznań Religijnych i Oświecenia Publicznego, sygn. 1004, Uzasadnienie projektu rozmieszczenia parafii prawosławnych, $1924 \mathrm{r}$.

${ }^{42}$ CAW, 3 DPL, sygn. I,313,3,2, Pismo dow. 3 DPL do ministra spraw wojskowych, 12 IV 1938, b.pag. 
cerkwi, a w każdym razie nie miały wartości architektonicznej i historycznej $^{43}$. Z drugiej jednak strony trzeba przyznać, że zniszczono też świątynie o charakterze zabytkowym, trwale wpisane w krajobraz kulturowy Chełmszczyzny i Podlasia.

Rozbiórki cerkwi przeprowadzono w ciągu dwóch miesięcy, od połowy maja do 16 lipca 1938 r., chociaż rozgłos, jaki im towarzyszył, trwał z większym lub mniejszym nasileniem aż do wybuchu wojny, a nawet dłużej. Nie ma jednomyślności co do liczby „zniesionych” obiektów. Pierwsze informacje na temat skali wyburzeń upublicznił poseł Ukraińskiego Zjednoczenia Narodowo-Demokratycznego (UNDO - Ukraïns'ke Nacìonal'no-Demokratične Ob'êdnannâ) Stepan Baran w interpelacji złożonej na początku drugiej połowy lipca 1938 r. Według jego informacji zniszczono 103 cerkwie i domy modlitw, 13 w powiecie bialskim, 9 w biłgorajskim, 20 w chełmskim, $33 \mathrm{w}$ powiecie hrubieszowskim, tyleż samo w powiecie tomaszowskim, 10 we włodawskim i 1 cerkiew w powiecie zamojskim. Najstarsze z nich pochodziły jeszcze sprzed XVI w. Zawarty w interpelacji wykaz dowodził, że większość obiektów powstała po $1875 \mathrm{r}^{44} \mathrm{Z}$ kolei w piśmie z 18 lipca $1938 \mathrm{r}$. wojewoda lubelski Jerzy de Tramecourt informował DOK II, że ogółem rozebrano 127 obiektów, z czego 91 cerkwi, 10 kaplic i 26 domów modlitw. Kościołowi katolickiemu przekazano 3 świątynie, natomiast w charakterze kostnic pozostawiono 4 kaplice. Poza tym w postaci zabytkowej ruiny pozostawiono częściowo rozebraną cerkiew w Szczebrzeszynie. W następstwie tych działań na terenie Lubelszczyzny pozostało 49 etatowych parafii prawosławnych, wraz z 5 filiami, oraz jeden klasztor, a więc powrócono do stanu z połowy lat dwudziestych ${ }^{45}$. Nie przypuszczam, żeby wojewoda lubelski chciał w tej sprawie wprowadzać w błąd miejscowe władze wojskowe i w związku z tym zaniżał bądź zawyżał liczbę zlikwidowanych obiektów. Z kolei usuwanie z Chełmszczyzny nieetatowych duchownych prawosławnych przedłużyło się do sierpnia $1938 \mathrm{r}^{46}$

Część historyków związanych z Kościołem prawosławnym rozszerza listę zlikwidowanych świątyń o obiekty spalone na krótko przed rozpoczęciem lub tuż po zakończeniu wyburzeń, obciążając tym stronę

${ }^{43}$ Wspominany już wcześniej ks. K. Grzesiak wymienia na terenie katolickiej diecezji lubelskiej 17 miejscowości, gdzie istniały takie przerobione z budynków prywatnych kaplice. Znajdowały się one w Lipinach, Biszczy, Księżpolu, Zamchu, Obszy, Chmielku, Terebiniu, Nieledwi, Horodle, Turkowicach, Sahryniu, Buśnie, Tarnawatce, Perespie, Chodywańcach, Szewni i Komarowie. K. Grzesiak, op. cit., s. 227.

${ }^{44}$ S. Baran, Cerkiew Prawosławna na Chełmszczyźnie. Przemówienia i interpelacje posłów i senatorów ukraińskich w Sejmie i Senacie, Lwów 1938, s. 44.

${ }^{45}$ CAW, DOK II, sygn. I,371,2,173, Pismo Urzędu Wojewódzkiego Lubelskiego do DOK II, 18 VII 1938, b.pag.

${ }^{46}$ CAW, 3 DPL, sygn. I,313,3,2, Akcja na b. Ziemi Chełmskiej, b.d., b.pag. 
polską ${ }^{47}$. Taki pogląd prezentuje między innymi G.J. Pelica ${ }^{48}$. Sprawców tych podpaleń nigdy nie wykryto, stąd równie prawdopodobne są trzy hipotezy.Jedna, że dokonali tego Polacy w ramach akcji likwidacyjnych. Druga, że sprawcami byli sami prawosławni, którzy spalili świątynie w obawie, by nie dostały się one w ręce katolików. Nie można wykluczyć również przypadków losowych.

Nie ulega wątpliwości, że na etapie przygotowania i organizacji akcji rozbiórkowych i likwidacji nieetatowych parafii prawosławnych na Chełmszczyźnie wojsko odegrało rolę kluczową. Gdy idzie natomiast o sam bezpośredni udział w niszczeniu świątyń, instrukcje dowództwa nakazywały zachowanie możliwie dużego dystansu i pozostawiania tego miejscowym organizacjom społecznym oraz strukturom administracji cywilnej. W praktyce wojsko było jednak zaangażowane w sam proceder niszczenia. Rozbiórek dokonywano na formalne zlecenie administracji lokalnej (starostów), przy pełnej koordynacji z integralnie powiązanymi z siłami zbrojnymi powiatowymi Komitetami Koordynacyjnymi. Przeprowadzały je jednostki straży pożarnej, przy udziale wynajętych robotników, a nawet więźniów. Niekiedy zachodziła też konieczność użycia do wyburzeń jednostek saperskich, zwłaszcza przy obiektach murowanych. Pełne wsparcie zapewniały struktury TRZW. Najczęściej odbywało się w ten sposób, że ekipa wyburzeniowa w asyście przedstawicieli administracji powiatowej i policji przybywała do danej miejscowości wczesnym rankiem. W przypadku cerkwi użytkowanych przez parafie nieetatowe, przed rozpoczęciem rozbiórki niekiedy zmuszano znajdujących się w najbliższej okolicy duchownych prawosławnych do wyniesienia z niej wszelkiego rodzaju przedmiotów kultu ${ }^{49}$. Odnotowywano jednak przypadki profanacji i bezczeszczenia świątyń oraz przykościelnych cmentarzy. Przy okazji rozbiórki niekiedy niszczono bezpowrotnie także parafialne biblioteki oraz archiwa ${ }^{50}$. W tym kontekście warto odnotować inicjatywę katolickiego biskupa lubelskiego Mariana Fulmana, który polecił miejscowym duchownym podjęcie działań, które miały zabezpieczyć prawosławne przedmioty kultu przed zniszczeniem ${ }^{51}$. Nad przebiegiem wyburzeń i ochroną przed nieprzewidzianymi zachowaniami ze

${ }^{47}$ Chodzi o podpalenia cerkwi w Żernikach i Mienianach, natomiast udało się ugasić pożary świątyń w Jurowie i Żabczu. Krótko po zakończeniu rozbiórek spłonęła również nie przewidywana do rozbiórki zabytkowa cerkiew w Święcicy. K. Grzesiak, op. cit., s. 226; J. Kania, op. cit., s. 38-39.

${ }^{48}$ G. J. Pelica, op. cit., s. 281.

${ }^{49}$ S. Baran, op. cit., s. 12 n.

${ }^{50}$ G. Kuprianowicz, op. cit., s. 41-45; M. Papierzyńska-Turek, op. cit., s. 360-361.

${ }^{51}$ J. Kania, op. cit., s. 48-52. 
strony miejscowej ludności prawosławnej czuwała policja. Na terenie gminy Nowa Osada odnotowano jednak przypadek, że policjanci z posterunku Łabunie w powiecie zamojskim raczej brali w obronę poszkodowaną ludność prawosławną ${ }^{52}$.

Zachowane w materiałach źródłowych oceny dotyczące przebiegu rozbiórek i stosunku do tychże ludności prawosławnej zależą od ich autorstwa. W sprawozdaniach przygotowanych przez przedstawicieli władz bądź na ich zlecenie, dominują opinie, że akcja przebiegała w spokoju, przy zazwyczaj biernej postawie wiernych, a nieliczne próby jej zakłócania likwidowane były w zarodku. Reprezentatywny w tym zakresie wydaje się reportaż Jana Wojnowskiego ze wsi Serebryszcze w powiecie chełmskim.

W dniu zniesienia miejscowej cerkwi Ukrainki zabrały wszystkie swoje dzieci z dziedzińca, tak, że zostało tylko jedno dziecko. Na ogół burzenie cerkwi odbyło się spokojnie, było tylko trochę płaczu. W ten sam dzień Rusin kupił sobie dach cerkiewny na stodołę, a materiał ze ścian cerkiewnych był wprost rozchwytywany przez miejscową ludność prawosławną na opał. Ludność więcej żałowała pieniędzy, które włożyła w remont cerkwi niż samej cerkwi.

Na koniec Wojnowski przytacza słowa jednego z miejscowych prawosławnych mieszkańców wsi: „Każde państwo robi u siebie porządek, Hitler u siebie robi porządek, to i Polska u siebie porządkuje" ${ }^{53}$. Z likwidacją pounickiej cerkwi w Serebryszczu łączy się jeszcze inne wydarzenie. Miejscową społeczność prawosławną sprzeciwiającą się jej utraty poparła rodzina należącego do Obozu Zjednoczenia Narodowego senatora Felicjana Lechnickiego. Córka senatora nie tylko odmówiła podpisania petycji miejscowych katolików o zwrot świątyni, ale również poinformowała o tym fakcie prawosławnych ${ }^{54}$. Przypadków protestów miejscowej inteligencji polskiej przeciw niszczeniu prawosławnych obiektów religijnych było więcej. Władze wojskowe bardzo krytycznie oceniały działalność prezesa Fundacji Staszicowskiej Stanisława Czekanowskiego, który ich zdaniem wręcz namawiał ludność prawosławną w Dziekanowie do stawiania czynnego oporu: „Ja teraz jadę do Warszawy -

${ }^{52}$ CAW, 3 DPL, sygn. I,313,3,2, mjr Jan Podziemski, Sprawozdanie z terenu gminy Nowa Osada pow. zamojski, 17 X 1938, b.pag.

${ }^{53}$ CAW, Oddz. II Szt. Gł., Sam. Ref. Inf. DOK II, sygn. 272/13, dr Jan Wojnowski, Reportaże z powiatów: kowelskiego, łuckiego, horochowskiego, włodzimierskiego i chełmskiego, 10 VII-25 VIII 1938, b.pag.

${ }^{54}$ CAW, 3 DPL, sygn. I,313,3,2, Pismo Tadeusza Broszkiewicza w zastępstwie sekretarza Komitetu Koordynacyjnego, Chełm, 15 VII 1938, b.pag. 
instruował - a gdyby tu przyjechali z zamiarem rozbierania cerkwi bierzcie pały i walcie ich po łbach" 55 .

Mimo uspokajających tonów, także w oficjalnych meldunkach pojawiają się informacje wskazujące na przejawy oporu wobec działań władz. Tak było między innymi we wsi Żerniki w powiecie tomaszowskim, gdzie doszło niemal do rozruchów. Jak donosiły władze wojskowe, „młodzież zaczęła się zbroić w widły, przygotowując się do rozpędzenia robotników zajętych przy rozbiórce. Do zajść nie doszło dzięki perswazji starszych wieśniaków i taktownemu zachowaniu się patrolu policyjnego"56.

$\mathrm{Z}$ kolei w dokumentach ukraińskich eksponowana jest martyrologia przywiązanych do swojej wiary wyznawców prawosławia. Wiele miejsca rozbiórkom prawosławnych obiektów sakralnych poświęcał najbardziej poczytny ukraiński dziennik „Diło” 57 . Inną równie dramatyczną relację $\mathrm{z}$ akcji burzenia cerkwi w Łaszczowie w powiecie tomaszowskim przedstawił z trybuny sejmowej poseł UNDO Baran:

W poniedziałek 4 lipca 1938 r. rano zjawił się koło cerkwi w Łaszczowie wójt Kazimierz Chmiel w asyście licznego oddziału policji państwowej z psem policyjnym oraz robotników Polaków z okolicznych miejscowości i od razu przystąpiono do burzenia cerkwi, jedynej świątyni prawosławnej na całą szeroką okolicę z kilku tysiącami wiernych prawosławnych. Na widok burzenia cerkwi zbiegła się pod cerkiew w ilości kilkuset ludzi, miejscowa ukraińska ludność prawosławna. Przybiegły małe dzieci, przyszli i starcy nad grobem, zjawiła się młodzież, kobiety i mężczyźni. Rozległ się straszny płacz i lament wśród zebranych prawosławnych. Wówczas policja państwowa puściła psa swego na małe dzieci, a starszych zaczęła bić pałkami gumowymi i okładać kolbami karabinów, starając się odpędzić ich od cerkwi. Wielu ludzi w tedy pobito. Policja utworzyła wówczas kordon dookoła cerkwi i asystowała przez cały czas burzenia cerkwi, trwający trzy $\mathrm{dni}^{58}$.

Nie ulega wątpliwości, że masowe niszczenie prawosławnych cerkwi i domów modlitw było katastrofalnym błędem politycznym polskich władz. Bardziej złożona jest natomiast sprawa podstaw prawnych podjętych działań. Choć część historyków i prawników twierdzi, że akcja niszczenia była

${ }^{55}$ CAW, Oddz. II Szt. Gł., Sam. Ref. Inf. DOK II, sygn. 1772,89,99, Pismo Dowództwa 3 DPL do płk. Sadowskiego, szefa Wydziału Bezpieczeństwa MSWojsk, 16 III 1939, b.pag.; ibidem, Oświadczenie Stanisława Greniuka, 15 III 1939, b.pag.

${ }^{56}$ CAW, DOK II, sygn. I,371,2,173, Pismo Samodzielnego Referatu Informacyjnego DOK II do Szefa Oddziału Sztabu Głównego w sprawie cerkwi prawosławnych w pow. tomaszowskim, 11 VII 1938.

${ }^{57}$ В., Нелєsально збудована цуерква. Допис із Холмщзини, „Dіло”, 18 VI 1938, nr 131.

58 S. Baran, op. cit., s. 41. 
całkowicie bezprawna, pozostają jednak wątpliwości. Wiążą się one ze sprawą własności niszczonych prawosławnych obiektów sakralnych. Miejscowe władze twierdziły, że były one mieniem państwowym. Podstawę do takiego stanowiska dawał dekret Naczelnika Państwa z 16 grudnia 1918 r., na mocy którego cały ruchomy i nieruchomy majątek pocerkiewny przeszedł w ręce państwa. Zlikwidowanych cerkwi, które wybudowane zostały przed rokiem 1918, nigdy nie przekazano Kościołowi prawosławnemu, chociaż takie plany istniały. Tak więc można zaryzykować stwierdzenie, że zniszczono obiekty, których właścicielem zgodnie z dekretem z 16 grudnia 1918 r. było Państwo Polskie, co wcale nie oznacza uznania zasadności ich rozbiórki. Tego rodzaju zastrzeżenie nie odnosi się jednak do kilkunastu domów modlitw powstałych w okresie międzywojennym w budynkach prywatnych zaadaptowanych na te cele. W tych przypadkach rozbiórka następowała niewątpliwie z pogwałceniem przepisów prawa własności. Trzeba też pamiętać, że mimo pojawiających się na łamach prasy ukraińskiej porad, zachęcających władze Kościoła prawosławnego do wystąpienia na drogę sądową w sprawie zniszczonych świątyń, aż do wybuchu wojny takich kroków nie podjęto ${ }^{59}$.

Rezonans społeczny, który towarzyszył akcji likwidacji tak wielu prawosławnych obiektów sakralnych w województwie lubelskim, w tym głosy krytyki płynące z zagranicy, chyba nieco zaskoczyły czynniki państwowe. Zwłaszcza że padały one również ze strony środowisk identyfikowanych dotychczas jako co najmniej przychylne władzy. Co więcej, miały miejsce przypadki ich czynnego zaangażowania po stronie prawosławnych. Przykładem tego mogła być wzmiankowana aktywność senatora OZN Lechnickiego i jego rodziny czy prezesa Fundacji Staszicowskiej. W tej sytuacji nawet MSWojsk zaczynało mieć wątpliwości, może nie co do samej zasady przedsięwzięcia, ale trafności zastosowanych metod polonizacji wschodnich i południowych powiatów Lubelszczyzny. Między innymi w związku z tym od sierpnia 1938 r. cała akcja rewindykacyjno-polonizacyjna wyraźnie przyhamowała. Zbiegło się to z jesienną kampanią przed wyborami do parlamentu, które zaplanowano na początek listopada tego roku.

Oczywiście nie zaniechano wszystkich działań. Zgodnie z instrukcjami dowództwa 3 DPL jeszcze w okresie wakacyjnym na Chełmszczyźnie i Podlasiu zorganizowano kilkadziesiąt półkolonii dla dzieci prawosławnych, których rodzice deklarowali przychylność wobec państwa polskiego lub $\mathrm{w}$ ostatnim czasie przeszli na katolicyzm ${ }^{60}$. Podczas kolejnych wakacji

59 O tego rodzaju podpowiedziach wspomina Roman Wysocki, „Akcja rewindykacyjna" a sytuacja Kościoła prawosławnego na Chełmszczyźnie w roku 1938 w świetle „Diła”, w: Akcja burzenia cerkwi prawosławnych, s. 186.

${ }^{60}$ CAW, Oddz. II Szt. Gł., Sam. Ref. Inf. DOK II, sygn. 1772,89,99, TRZW, koło 
przedsięwzięcie to miało być realizowane na większą skalę, z pomocą TRZW $^{61}$. Kontynuowano też rozpoczętą wcześniej akcję zmian nazwisk i nazw miejscowości, tak by brzmiały one bardziej polsko ${ }^{62}$. Ta swego rodzaju walka o nazwiska miała jednak charakter bardziej dwustronny, niż to się powszechnie wydaje, ponieważ również miejscowi popi w prowadzonych przez siebie księgach parafialnych nierzadko „ruszczyli” polsko brzmiące nazwiska swoich wiernych ${ }^{63}$.

Zarówno w okresie rozbiórek cerkwi, jak i później władze administracyjne intensyfikowały inne działania zmierzające do spolonizowania prawosławia. Na duchownych wywierano presję, aby kazania i prowadzenie lekcji religii odbywało się w języku polskim. Repertuar środków nacisku był różnorodny, ale nie zawsze wymykał się rygorom prawa. Najczęściej inspirowano wiernych, by na zebraniach parafialnych podejmowali uchwały z żądaniami nabożeństw w języku polskim. Wobec duchownych, którzy sprzeciwiali się tego rodzaju postulatom, stosowano różne formy szykan, włącznie z karami grzywny czy decyzjami o wydaleniu $\mathrm{z}$ danego terenu ${ }^{64}$. Sytuacja duchowieństwa prawosławnego była w tym względzie wyjątkowo trudna, ponieważ naciski szły też z drugiej strony. Metropolita Dionizy przestrzegał, że podporządkowanie się żądaniom władz grozić będzie sankcjami kościelnymi, z możliwością zawieszenia w funkcjach duszpasterskich włącznie. Według dokumentów wojskowych dotknąć one miały Jana Karwowskiego, prawosławnego proboszcza i dziekana w Chełmie, który lojalnie podporządkował się instrukcjom władz administracyjnych ${ }^{65}$. Ppłk Sosabowski i inni dowódcy na Chełmszczyźnie bardzo krytycznie oceniali tego rodzaju posunięcia głowy Kościoła prawosławnego. W raportach zwracano uwagę, że „Zakaz metropolity Dionizego wygłaszania kazań po polsku wpłynął b. ujemnie na akcję polszczenia prawosławnych i podważył bardzo powagę zarządzeń władz państwowych, nakazujących wprowadzenie tych kazań, za-

w Krasnymstawie. Protokół nr 9, 27 X 1938, b.pag. Akcja organizowania półkolonii szczególnie rozwinięta była w województwach południowo-wschodnich. W lecie 1938 r. objęto nimi ponad 250 dzieci wiejskich z województw: lwowskiego, stanisławowskiego i tarnopolskiego.

${ }^{61}$ Ibidem, Pismo TRZW, Oddział w Hrubieszowie do Zarządu TRZW, Okręg Lublin, 28 I 1939, b.pag.

${ }^{62}$ Przykładowo TRZW w Zamościu domagało się zmiany nazwy miejscowości Ruskie Piaski. CAW, 3 DPL, sygn. I,313,3,2, Protokół z zebrania Obwodu TRZW, 2 III 1939, b.pag.

${ }^{63}$ Ibidem, Pismo płk. M. Turkowskiego, kierownika akcji koordynacyjnej, 23 I 1939, b.pag.

${ }^{64}$ G. Kuprianowicz, op. cit., s. 67.

${ }^{65}$ CAW, Oddz. II Szt. Gł., Sam. Ref. Inf. DOK II, sygn. 1772,89,99, Pismo komendanta Obwodu PW nr 7 w Chełmie do dow. 3 DPL, 20 VIII 1938, b.pag. 
chwiał przy tym w ludności prawosławnej wiarę w siłę egzekutywną władz państwowych" ${ }^{66}$. Istniała też presja ze strony samych wiernych, tak można bowiem interpretować przypadki demonstracyjnego opuszczania świątyń podczas wygłaszania kazań w języku polskim ${ }^{67}$.

W warunkach poczucia zagrożenia spowodowanego działaniami władz państwowych na Chełmszczyźnie i Podlasiu Południowym następowała szybka integracja społeczeństwa prawosławnego i ożywienie życia religijnego. Przyśpieszenia nabierał proces ukrainizacji miejscowych wyznawców prawosławia. Jeżeli jeszcze przed rokiem 1938 stosunkowo łatwo wyodrębnić można było tu grupę ludności polskiej tego wyznania, którą szacowano na co najmniej $10 \%$ ogółu, to po rozbiórkach cerkwi ukraińska identyfikacja narodowa stawała się niemal powszechna. Na miejsce usuniętych księży nieetatowych przybywali nowi, bardziej radykalni i zdeterminowani w działalności duszpasterskiej oraz narodowościowej, umiejący lepiej zakonspirować swoją aktywność pozareligijną ${ }^{68}$. Pracy ich sprzyjała atmosfera oparta na skojarzeniach z sytuacją pierwszych chrześcijan prześladowanych za wiarę. W ocenach władz wojskowych, w latach 1938-1939 w województwie lubelskim istniała ścisła współpraca pomiędzy wieloma duchownymi prawosławnymi a bojowcami Organizacji Ukraińskich Nacjonalistów ${ }^{69}$.

Władze wojskowe i administracyjne na Lubelszczyźnie na bieżąco monitorowały sytuację religijną i narodowościową w regionie. Wyciągały z niej jednoznaczne wnioski. Dominowało przekonanie, że dotychczasowe działania, których celem było uniemożliwienie działalności nieetatowych duchownych prawosławnych, okazały się niewystarczające. Skutecznym antidotum na przejawy ukrainizacji Cerkwi na Chełmszczyźnie oraz działalność pozareligijną duchowieństwa prawosławnego miały teraz być masowe rewindykacje wyznaniowe i dalsze polszczenie Cerkwi. Podczas spotkania TRZW w Krasnymstawie przekonywano: „dawniej popowi prawosławnemu robili szykany komuniści, obecnie zaś wszyscy się zlali i nawet greko-katolicy trzymają się razem. [- - ] terrorem z prawosławnymi nic nie zrobimy, a należy polszczyć cerkiew prawosławną"70.

${ }^{66}$ Ibidem, Resumé działalności na terenie b. ziemi chełmskiej, październik 1938,b.pag.

${ }^{67}$ Ibidem, Sprawozdanie z powiatu Tomaszów Lubelski, b.d., b.pag.

${ }^{68}$ CAW, Oddz. II Szt. Gł., Sam. Ref. Inf. DOK II, sygn. 1772,89,99, Meldunek sytuacyjny tygodniowy 7 Pułku Piechoty Legionów do dow. 3 DPL, 17 X 1938, b.pag.

${ }^{69}$ Ibidem, oraz Pismo TRZW, koło Tomaszów Lubelski do kierownika akcji koordynacyjnej, 15 X 1938, b.pag.

${ }^{70}$ Ibidem, Pismo komendanta Obwodu PW nr 7 w Chełmie do dow. 3 DPL, 20 VIII 1938, b.pag. 
Na podstawie nadsyłanych do dowództwa 3 DPL analiz sytuacji i wniosków z dotychczasowych działań, 24 stycznia 1939 r. płk Turkowski rozesłał do podległych mu kierowników Komitetów Koordynacyjnych nowe wytyczne w sprawie akcji rewindykacyjno-polonizacyjnej na Chełmszczyźnie i Podlasiu, ujęte w ośmiu punktach ${ }^{71}$. Zbiegło się to w czasie z przyjętym przez władze wojewódzkie trzyletnim programem odukrainizowania administracji państwowej na Lubelszczyźnie ${ }^{72}$. Najbardziej niepokojąco brzmiał punkt piąty:

Stać twardo na stanowisku, że w Polsce tylko Polacy są gospodarzami, pełnoprawnymi obywatelami i tylko oni mają coś do powiedzenia. Wszyscy inni są tylko tolerowani. Wytworzyć wśród mas polskich kompleks wyższości w stosunku do ludności niepolskiej. Mowa polska musi być wyrazem wyższości tak kulturalnej,jak i obywatelskiej. Polak musi zwracać się do ludności niepolskiej tylko po polsku. A już w żadnym wypadku funkcjonariusz państwowy czy też samorządowy nie może używać innego języka niż polski ${ }^{73}$.

Trudno inaczej niż negatywnie oceniać pomysły ograniczania praw ze względu na pochodzenie narodowe, natomiast trzeba zaznaczyć, że wymóg używania języka państwowego w urzędach i instytucjach bywa normą stosowaną także współcześnie w wielu demokratycznych państwach prawa. Poza tym trzeba pamiętać, że w przypadku akcji rewindykacyjno-polonizacyjnej w woj. lubelskim mamy niekiedy do czynienia z sytuacjami, kiedy zapowiedzi władzy odbiegały od tego, co zostało wdrożone w życie. W praktyce działania okazywały się mniej represywne, niż wskazywały na to plany. Czasami brakowało też konsekwencji w urzeczywistnianiu radykalnych pomysłów rządzących. Składały się na to różne przyczyny. Wydaje się, że w społeczeństwie polskim raczej nie było przyzwolenia na daleko idące ograniczenia szeroko pojmowanych swobód obywatelskich. Nawet w aparacie administracyjnym zdarzały się przypadki kontestowania bardziej radykalnych decyzji czynników zwierzchnich. Przykładem tego może być prezentowane wcześniej zachowanie policji państwowej z posterunku Łabunie, która brała w obronę ludność prawosławną. Z kolei na terenie gminy Nowa Osada w powiecie zamojskim po zlikwidowaniu wszystkich prawosławnych parafii

${ }^{71}$ CAW, 3 DPL, sygn. I,313,3,2, Pismo kierownika akcji koordynacyjnej płk. M. Turkowskiego, 24 I 1939, b.pag.

${ }^{72}$ AP w Lublinie, Urząd Wojewódzki Lubelski, sygn. 428, Projekt trzyletniego odukrainizowania służby publicznej na terenie woj. lubelskiego,b.d.,b.pag.

${ }^{73}$ CAW, 3 DPL, sygn. I,313,3,2, Pismo kierownika akcji koordynacyjnej płk. M. Turkowskiego, 24 I 1939, b.pag. 
nieetatowych, jesienią 1938 r. - mimo zakazów czynników wojskowych władze administracyjne wydawały zgody na odprawianie nabożeństw poza parafiami etatowymi ${ }^{74}$. Chyba najbardziej charakterystycznym dowodem na sygnalizowany brak konsekwencji była sprawa używania języka polskiego podczas nabożeństw prawosławnych. Władze województwa lubelskiego oraz Komitet Koordynacyjny przy DOK II mocno zabiegały o używanie języka polskiego podczas nabożeństw, tymczasem MWRiOP opublikowało wyjaśnienia, w myśl których podczas nabożeństw prawosławnych modlitwa za Rzeczpospolitą, prezydenta i armię miała być wygłaszana w języku polskim tylko wtedy, kiedy byli na niej przedstawiciele $w_{ł a d z}{ }^{75}$. Tego typu przykładów można przytoczyć więcej. Dostrzegały ten problem także władze wojskowe. W ocenie ppłk. Sosabowskiego „niezdecydowanie i niekonsekwentne postępowanie władz państ. przynosi akcji nieobliczalne szkody, stawiając sprawę w gorszej sytuacji aniżeli była przed rozpoczęciem akcji"76. Z drugiej strony nie można nie zauważyć przypadków pryncypialnego przestrzegania zaleceń władz zwierzchnich i w konsekwencji łamania prawa.

Przedstawiciele wojska uskarżali się również na brak adekwatnego zaangażowania w akcję rewindykacyjną ze strony duchowieństwa katolickiego. Jego postawa wyrastająca z poczucia stabilizacji, rutyny, a może także dystansu wobec przymusowych konwersji miała kontrastować z żarliwością w obronie wiary i narodowości wielu księży prawosławnych i grekokatolickich ${ }^{77}$.Zwracał na to uwagę płk Turkowski w piśmie do dowódcy OK w Lublinie: „W odróżnieniu od popów dziwnie bierne jest stanowisko księży rzym.-kat. [- - ], którzy aczkolwiek są członkami TRZW, to jednakowoż żadnej działalności nie przejawiają"78.

Wytyczne dowódcy 3 DP płk. Turkowskiego z 24 stycznia 1939 r. kładły nacisk na zwalczanie wszelkich przejawów działalności narodowościowej mniejszości ukraińskiej we wschodnich i południowych powiatach Lubelszczyzny. $Z$ założenia postrzegana ona była jako antypaństwowa, w myśl przyjętej wcześniej tezy, że Chełmszczyzna i Podlasie

\footnotetext{
${ }^{74}$ Ibidem, mjr J. Podziemski, Sprawozdanie z gminy Nowa Osada, pow. zamojski, 17 X 1938, b.pag.

${ }^{75}$ CAW, Oddz. II Szt. Gł., Sam. Ref. Inf. DOK II, sygn. 1772,89,99, Pismo kierownika akcji koordynacyjnej na pow. Chełm, Luboml, Krasnystaw, płk. W. Muzyki, do dow. 3 DPL, 4 IV 1939, b.pag.

${ }^{76}$ Ibidem, Resumé działalności na terenie b. ziemi chełmskiej, październik 1938,b.pag.

${ }^{77}$ Ibidem, Pismo komendanta powiatowego Wychowania Fizycznego i Przysposobienia Wojskowego w Tomaszowie Lubelskim do dow. 3 DPL, 20 I 1939, b.pag.; ibidem, TRZW, koło w Krasnymstawie. Protokół nr 9, 27 X 1938, b.pag.

${ }^{78}$ Ibidem, Pismo kierownika akcji koordynacyjnej na Lubelszczyźnie do dow. OK II Komitet Koordynacyjny, 9 XI 1938, b.pag.
} 
Południowe powinny być wolne od wpływów ukraińskich. Według DOK II linia Bugu wyznaczać powinna zachodnią granicę wpływów ukraińskich w Polsce. Podkreślić należy, że w żadnych planach nie przewidywano ani masowych przesiedleń miejscowej mniejszości ukraińskiej, ani tym bardziej jej eksterminacji. Likwidacja zagadnienia ukraińskiego na tych obszarach nastąpić miała w wyniku „masowych powrotów” na łono Kościoła rzymskokatolickiego. Polonizację realizować zamierzano poprzez faworyzowanie ludności polskiej w sferze gospodarczej, odpowiednią politykę parcelacyjną, ofensywę propagandową z eksponowaniem haseł o mocarstwowej roli Polski oraz aktywizowanie misyjnej działalności Kościoła rzymskokatolickiego ${ }^{79}$. Wszystko to winno prowadzić do sytuacji, w której miejscowej ludności ukraińskiej opłacać się miało materialnie przejście na katolicyzm, co w ocenie władz wojskowych równoznaczne było z identyfikacją narodową. Wsparcie dla tego rodzaju działań zapewniać miał aparat administracyjny, instytucje gospodarcze oraz struktury Kościoła katolickiego. Wobec duchownych prawosławnych oraz ukraińskich działaczy politycznych nie respektujących poleceń władz stosowano represje, polegające na aresztowaniach i szykanach administracyjnych z wysiedleniem z Lubelszczyzny włącznie ${ }^{80}$.

Zarówno czynniki wojskowe, jak i władze cywilne nigdy nie ukrywały, że po zlikwidowaniu parafii nieetatowych i wprowadzeniu języka polskiego do kazań oraz katechezy rewindykacja dusz ma być kolejnym etapem na drodze do asymilacji językowej i narodowej ludności prawosławnej na Lubelszczyźnie ${ }^{81}$. Według instrukcji MWRiOP z lutego 1939 r. miała ona odbywać się jednak z zachowaniem całkowitej dobrowolności ${ }^{82}$. Rzeczywistość często okazywała się jednak inna. W instrukcjach władz wojskowych także akcentowano konieczność stosowania metod zgodnych z prawem. Tak było w przypadku dowódcy 7 Pułku Piechoty w Chełmie, który wytyczne dotyczące rewindykacji wyznaniowych sformułował w sześciu podpunktach:

a) Wpływać na prawosławnych perswazją, wskazując im, że dawniej byli katolikami lub unitami, a przeszli na prawosławie pod batem cara. b) Wpływać drogą działania kultury polskiej (świetlice, przedstawienia itp.).c) drogą opieki nad dziećmi (półkolonie, dziecińce). d) Pilnować by popi nie prowadzili agitacji, oraz by dzieci w szkołach nie odmawiali

${ }^{79}$ CAW, 3 DPL, sygn. I,313,3,2, Pismo kierownika akcji koordynacyjnej płk. M. Turkowskiego, 24 I 1939, b.pag.

${ }^{80}$ Ibidem, mjr J. Podziemski, Sprawozdanie z gminy Nowa Osada, pow. zamojski, 17 X 1938, b.pag.

${ }^{81}$ Ibidem, Akcja na b. Ziemi Chełmskiej, b.d., b.pag.

${ }^{82}$ K. Grzesiak, op. cit., s. 435. 
modlitwy w języku ruskim. e) Dopilnować by członkowie TRZW lub jakiejkolwiek jednostki nie występowały agresywnie w stosunku do prawosławnych. f) Otaczać opieką tak duchową jak i finansową konwertytów [pisownia oryg. - J.K.] . $^{83}$.

W praktyce również na jego terenie podległym dowódcy pułku zorganizowana presja na rzecz konwersji wykraczała zarówno poza ramy dopuszczalne przez moralność, jak i zasady prawa.

Często stosowano różnego rodzaju formy uprzywilejowywania konwertytów, a w przypadku opornych przymus ekonomiczny. Repertuar środków był zróżnicowany, obliczony na to, żeby - zgodnie z zamierzeniami władz - „opłacało się być Polakiem”. W niektórych gminach organizowano kasy bezprocentowe, które udzielały pożyczek tylko ludności polskiej oraz rewindykowanym. Tym ostatnim starano się zapewnić też inne formy wsparcia materialnego w postaci dożywiania, ubrań, butów, bezpłatnych porad lekarskich. W okresie wakacyjnym do gmin, gdzie następowały liczne konwersje, mieli być kierowani studenci z zadaniami udzielania porad prawnych, wsparcia w kontaktach $\mathrm{z}$ administracją. Innego rodzaju środki to organizowanie w tych gminach dziecińców, półkolonii, domów i uniwersytetów ludowych, bibliotek oraz akcji propagandowych z wykorzystaniem kina objazdowego. Dla młodych dziewcząt $z$ rodzin konwertytów organizowano bezpłatne kursy kroju i szycia ${ }^{84}$.

Z kolei częstą formą przymusu ekonomicznego było pomijanie prawosławnych w parcelacjach gruntów. Nie zawsze okazywało się to jednak skuteczne, czego dowodem był przypadek parcelacji folwarku Wierzchowiny w powiecie krasnostawskim. Wśród nabywców gruntów znalazło się 11 prawosławnych rolników z okolicznych wiosek. TRZW sugerowało uzależnienie nabycia tej ziemi od decyzji o przejściu na katolicyzm. Mimo to władze wojewódzkie w Lublinie zatwierdziły bez żadnych zastrzeżeń listę nabywców, w tym owych 11 prawosławnych. Miejscowy starosta mógł jedynie przez jakiś czas odwlekać podjęcie decyzji wykonawczych ${ }^{85}$.

Polityka parcelacyjna zmierzała do tego, żeby oddzielić pasem wiosek jednolicie polskich obszar Lubelszczyzny od Małopolski Wschodniej. Po tej stronie kordonu sokalskiego dotyczyło to powiatu tomaszowskiego

${ }^{83}$ CAW, Oddz. II Szt. Gł., Sam. Ref. Inf. DOK II, sygn. 1772,89,99, Pismo dow. 7 Pułku Piechoty Legionów do dow. 3 DPL, 1 V 1939, b.pag.

${ }^{84}$ Ibidem, Pismo TRZW, koło Tomaszów Lubelski do dow. 3 DPL, 13 II 1939, b.pag; CAW, 3 DPL, sygn. I,313,3,2, Protokół z zebrania Zarządu Obwodu TRZW, które odbyło się w Inspektoracie szkolnym w Zamościu 2 III 1939, b.pag.

${ }^{85}$ CAW, Oddz. II Szt. Gł., Sam. Ref. Inf. DOK II, sygn. 1772,89,99, Pismo TRZW, koło w Krasnymstawie do W. płk. M. Turkowskiego, dow. 3 DPL, 11 V 1939, b.pag. 
i biłgorajskiego ${ }^{86}$. W innych dopuszczano do udziału w parcelacjach lojalnych wobec państwa prawosławnych chłopów, ale tylko tak, by na dwóchtrzech Polaków przypadał jeden Ukrainiec. Miało to zabezpieczać przed powstawaniem lokalnych skupisk ludności niepolskiej ${ }^{87}$.

Ze stosowaniem przymusu ekonomicznego łączyła się również kwestia koncesji na szczególnie opłacalną na Lubelszczyźnie uprawę buraka cukrowego oraz tytoniu. Nie dotyczyło to jakiejś licznej grupy plantatorów, niemniej jednak zasługuje na szczegółowe wyświetlenie. TRZW w powiecie zamojskim podjęło starania o odebranie kilkunastu Ukraińcom związanym z działalnością narodowościową i religijną koncesji na uprawę buraka cukrowego i tytoniu. W tej sprawie interweniowano między innymi w Zarządzie Głównym Związku Stowarzyszeń Plantatorów Buraka Cukrowego w Warszawie. Z kolei po stronie ukraińskich plantatorów w pisanie odwołań angażowali się miejscowi duchowni prawosławni ${ }^{88}$. Opierając się na zachowanych dokumentach, nie jesteśmy w stanie ustalić, jakie były w tej sprawie ostateczne rozstrzygnięcia.

Wraz z konwersjami na katolicyzm trwała akcja „oczyszczania” miejscowych spółdzielni z Ukraińców oskarżanych o działalność narodową ${ }^{89}$. Pojawił się nawet pomysł, żeby do działalności polonizacyjnej na Chełmszczyźnie wykorzystać agentów ubezpieczeniowych mających z natury swojej pracy częsty kontakt z mieszkańcami ${ }^{90}$.

O pozaprawnych metodach zmuszania do konwersji na katolicyzm szeroko pisze, głównie w oparciu o relacje proboszczów parafii prawosławnych, ks. Krzysztof Grzesiak. Kontrastują one ze sprawozdaniami TRZW i meldunkami władz administracyjnych, według których niemal wszystko odbywało się na drodze dobrowolności i legalizmu. Z przytoczonych dokumentów wyłania się jednak ponury obraz nacisków z elementami szantażu, a nawet terroru, przeprowadzanych przy wsparciu lokalnych władz ${ }^{91}$.

${ }^{86}$ Ibidem, Pismo TRZW, koło w Biłgoraju, 13 II 1939, b.pag.

${ }^{87}$ Ibidem, Pismo TRZW, koło Tomaszów Lubelski do dow. 3 DPL, 13 II 1939, b.pag.

${ }^{88}$ CAW, 3 DPL, sygn. I,313,3,2, Protokół z zebrania Zarządu Obwodu TRZW, które odbyło się w Inspektoracie szkolnym w Zamościu 2 III 1939, b.pag.; ibidem, Pismo Zarządu Powiatowego TRZW w Zamościu do Zarządu Głównego Związku Stowarzyszeń Plantatorów Buraka Cukrowego w Warszawie, 21 III 1939, b.pag.; ibidem, Powiat Zamość. Sprawozdanie, 6 VI 1939, b.pag.

${ }^{89}$ CAW, Oddz. II Szt. Gł., Sam. Ref. Inf. DOK II, sygn. 1772,89,99, Rezultaty akcji rewindykacyjnej do dnia 18 V 1939 r. Powiat Hrubieszów, 20 V 1939, b.pag.; ibidem, Pismo TRZW, koło Tomaszów Lubelski do dow. 3 DPL, 13 II 1939, b.pag.; CAW, 3 DPL, sygn. I,313,3,2, Pismo Dowództwa 3 DPL do ppłk. Sadowskiego, szefa Wydziału Bezpieczeństwa MSWojsk, 1 III 1939, b.pag.

${ }^{90}$ CAW, 3 DPL, sygn. I,313,3,2, Pismo Dowództwa 3 DPL, 4 IV 1939, b.pag.

${ }^{91}$ K. Grzesiak, op. cit., s. 436-437. 
Scenariusz akcji „nawracania na katolicyzm” na Chełmszczyźnie i Podlasiu przypominał ten zastosowany ponad rok wcześniej w województwie wołyńskim. Wszędzie w roli „misjonarzy” wykorzystywano przedstawicieli administracji oraz odpowiednio dobranych liderów środowisk polskich w asyście policji. Gdzieś w drugim planie zazwyczaj pojawiali się też oficerowie Wojska Polskiego. Przejście na katolicyzm wymuszane było zorganizowaną presją, a nawet terrorem i nagradzane korzyściami materialnymi. Dobrze odzwierciedlają to wydarzenia, które rozegrały się w 1939 r. we wsi Nowosiółki w parafii Moniatycze (pow. hrubieszowski), zrelacjonowane przez proboszcza miejscowej parafii prawosławnej. Ostatecznie w marcu i kwietniu 1939 r. wyznanie zmieniło 248 prawosławnych mieszkańców Nowosiółek i okolic ${ }^{92}$. Konwertyci nagradzani byli w różny sposób, np. w powiecie hrubieszowskim ponad 200 osób otrzymało stałe lub sezonowe zatrudnienie w cukrowniach i innych przedsiębiorstwach. Zapewniano im również pracę w okolicznych folwarkach ${ }^{93}$.

Akcję rewindykacyjną łączono z kreowaniem nowych parafii rzymskokatolickich, placówek oświatowych, domów ludowych czy innego rodzaju polskich instytucji kulturalnych. Zakładano, że na każde 2500 konwertowanych dusz powinna powstać w danej okolicy nowa parafia katolicka. Zdawano sobie sprawę, że nie może to nastąpić natychmiast, w związku $z$ tym proponowano utworzenie $10 \mathrm{tzw}$. prefektur objazdowych, finansowanych z dodatkowych funduszy MWRiOP. Jednocześnie przekonywano, że konieczne jest szybkie wysłanie na teren Chełmszczyzny 10 księży katolickich, którzy od razu podjęliby działalność duszpasterską. , Jeżeli Episkopat Lubelski dać nie chce lub nie może, winien to uczynić inny"94.

Ludność prawosławna stosowała różne formy obrony przed presją władz. Niektórzy księża prawosławni rozpowszechniali plotkę, jakoby przechodzeniu współwyznawców na katolicyzm przeciwny był marszałek Edward Rydz-Śmigły ${ }^{95}$. Wszelkie formy biernego oporu wspierali działacze ukraińscy, zarówno miejscowi,jak i napływający z Małopolski Wschodniej. Niekiedy stosowano nawet groźby. Na początku 1939 r. w powiecie tomaszowskim OUN kolportowała ulotki zawierające ostrzeżenie: „Nie przechodź na katolicyzm - będzie Ukraina, Hitler nam ją odbuduje, a ty zostaniesz zabity" ${ }^{16}$. Niekiedy z pomocą przychodziła im również miejscowa

92 Ibidem, s. 438-439 i 446.

${ }^{93}$ CAW, Oddz. II Szt. Gł., Sam. Ref. Inf. DOK II, sygn. 1772,89,99, Rezultaty akcji rewindykacyjnej do dnia 18 V 1939 r. Powiat Hrubieszów, 20 V 1939, b.pag.

${ }_{94}$ CAW, 3 DPL, sygn. I,313,3,2, Akcja na b. Ziemi Chełmskiej, b.d., b.pag.

${ }_{95}$ Ibidem, Pismo TRZW do płk. Turkowskiego, wiceprezesa TRZW, Zamość, 7 V 1939, b.pag.

${ }^{96}$ CAW, Oddz. II Szt. Gł., Sam. Ref. Inf. DOK II, sygn. 1772,89,99, Pismo komendanta powiatowego PW i WF w Tomaszowie Lubelskim do dow. 3 DPL, 20 I 1939, b.pag. 
inteligencja polska. Tak było na przykład w Biszczy, powiat biłgorajski, gdzie miejscowy nauczyciel instruował: „nie słuchajcie ich, bo nie ma prawa, żeby was zmusić do przejścia na wiarę rzym.-kat. - Polska nie lubi perekińczyków [tj. renegatów]". O podobne zachowania oskarżana była również nauczycielka gimnazjum z Biłgoraja, prywatnie żona kapitana Korpusu Ochrony Pogranicza, oraz niejaki Dobrowolski, delegat Związku Drobnych Rolników i Robotników Rolnych, który zniweczyć miał akcję konwersyjną w Łazorach. Władze TRZW uskarżały się również na utrudnianie akcji rewindykacyjnej ze strony niektórych organów administracji wojewódzkiej oraz władz szkolnych ${ }^{97}$. W kwietniu 1939 r. we wsi Horyszów Ruski doszło nawet do aresztowania czterech Polaków zaangażowanych w akcję rewindykacyjną. Nie wiemy dokładnie, co było tego bezpośrednim powodem. Tak czy inaczej, zostało to sprytnie wykorzystane przez Ukraińców, którzy przekonywali okoliczną ludność, by „nie bać się policji i przestępstw przeciw państwu, bowiem od spraw politycznych jest w Zamościu w policji naczelnik wydziału śledczego [nazwisko nieczytelne - J.K.] prawosławny - który broni ich w każdej sprawie" 98 .

Prawdopodobnie właśnie w związku z aresztowaniem wspomnianych Polaków, 26 kwietnia 1939 r. płk Turkowski złożył wniosek o przeniesienie na inne stanowisko. Sprawa jest wyjątkowo niejasna. Znamy ją jedynie $\mathrm{z}$ odpisu jednego krótkiego dokumentu znajdującego się w zespole akt 3 DPL. W odpisie brakuje adresata, wiemy jedynie, że był on w stopniu pułkownika, prawdopodobnie w MSWojsk. Płk Turkowski prosił w liście o wpłynięcie na dyrektora Borkowskiego, by nie zawieszać w czynnościach wójtów i sołtysów oraz nie przenosić na inny teren nauczycieli związanych z akcją polonizacyjną. Kończy swój list następująco: „Osobiście wniosłem podanie o przeniesienie, gdyż poczuwam się do pewnej odpowiedzialności co do ideowego nastawienia w tych sprawach, mogę więc spokojnie i z czystym sumieniem prosić Pana Pułkownika o interwencję w tej sprawie" ${ }^{99}$. Być może interwencja okazała się skuteczna i dowódca 3 Dywizji wycofał swoją prośbę o przeniesienie, albo też nie została ona przyjęta przez przełożonych.

Mimo zaangażowania dużych środków i wielu instytucji wymierne liczone liczbą konwertytów - rezultaty akcji na Chełmszczyźnie i Podlasiu Południowym okazały się co najmniej skromne. Nawet władze wojskowe

${ }^{97}$ Ibidem, Sprawozdanie z akcji propagandowej. Pismo 9 Pułku Piechoty Legionów do dow. 3 DPL, 11 IV 1939, b.pag.

${ }^{98}$ CAW, 3 DPL, sygn. I,313,3,2, mjr J. Podziemski, Sprawozdanie z terenu gminy Nowa Osada, pow. zamojski, 17 X 1938, b.pag.

${ }^{99}$ Ibidem, Pismo płk. M. Turkowskiego z dnia 26 IV 1939, b.pag. 
przyznawały, że przechodzenie prawosławnych na rzymski katolicyzm nie ma charakteru spontanicznego i masowego ${ }^{100}$. Szczegółowe wyliczenia dla diecezji lubelskiej na podstawie niezachowanych w komplecie Liber conversorum podaje ks. K. Grzesiak ${ }^{101}$. Luki w materiale źródłowym uniemożliwiły mu jednak sprecyzowanie ogólnej liczby prawosławnych, którzy ostatecznie zmienili wyznanie. Nie potrafiły tego podliczyć także ówczesne władze wojskowe ani administracja cywilna. Tak czy inaczej, w oparciu o sumienne, choć cząstkowe wyliczenia ks. Grzesiaka oraz równie niepełne materiały instytucji związanych z wojskiem można bez większej obawy o błąd zaryzykować stwierdzenie, że liczba konwertytów na Lubelszczyźnie nie była większa niż kilkanaście tysięcy osób. A zatem nie przekroczyła nawet $10 \%$ wszystkich wyznawców prawosławia ${ }^{102}$. Według danych wojskowych największy zasięg konwersje miały w powiecie hrubieszowskim, gdzie wyznanie zmieniło około 4500 osób. Oceniano jednak, że w najbliższym czasie około $1800 \mathrm{z}$ nich ponownie wróci do prawosławia ${ }^{103}$. Z kolei w powiecie zamojskim do końca maja 1939 r. wyznanie zmieniło 1800 osób ${ }^{104}$. W pozostałych powiatach województwa lubelskiego rozmiary konwersji były znacząco mniejsze.

Program rewindykacyjno-polonizacyjny przygotowany został przede wszystkim z myślą o poprawie obronności Rzeczypospolitej i z tego punktu widzenia w pierwszej kolejności należałoby rozpatrywać jego rezultaty. Konfrontacja efektów z zamiarami wypada jednoznacznie negatywnie. Trudno odmówić armii prawa do działań zmierzających do zapewnienia państwu i społeczeństwu poczucia bezpieczeństwa w warunkach zagrożenia w drugiej połowie lat trzydziestych, także szukania takich rozwiązań, które wychodzą poza mury koszar, zmierzają do przygotowania mieszkańców kraju i całego organizmu państwowego na wypadek wojny. Tego rodzaju inicjatywy miały pełne oparcie w przyjętych rozwiązaniach legislacyjnych i były stosowane w wielu krajach europejskich. Zupełnie inną sprawą jest natomiast sposób ich realizacji. Zastosowane środki, takie jak niszczenie prawosławnych cerkwi i domów modlitw oraz nawracanie siłą na katolicyzm, przyniosło skutki odwrotne od zamierzonych. W efekcie akcja rewindykacyjno-polonizacyjna nie tylko osłabiła zdolności obronne Rzeczypospolitej, ale również podkopywała autorytet całego

100 CAW, Oddz. II Szt. Gł., Sam. Ref. Inf. DOK II, sygn. 1772,89,99, Resumé działalności na terenie b. ziemi chełmskiej, październik 1938, b.pag.

${ }^{101}$ K. Grzesiak, op. cit., s. 445-452.

102 P. Stawecki, op. cit., s. 196.

${ }^{103}$ CAW, Oddz. II Szt. Gł., Sam. Ref. Inf. DOK II, sygn. 1772,89,99, Rezultaty akcji rewindykacyjnej do dnia 18 V 1939 r. Powiat Hrubieszów, 20 V 1939, b.pag.

104 CAW, 3 DPL, sygn. I,313,3,2, Powiat Zamość. Sprawozdanie, 6 VI 1939, b.pag. 
państwa. Na Chełmszczyźnie i Podlasiu Południowym zrodziła wyjątkowo niebezpieczną atmosferę wojny religijnej z udziałem instytucji państwowych po jednej stronie i mniejszości ukraińskiej po drugiej. Jeżeli decyzje o rozbiórkach prawosławnych obiektów religijnych w 1938 r. motywowano obawami o to, żeby nie stały się one ośrodkami nacjonalizmu ukraińskiego, to po ich zburzeniu wiele pozostałych parafii właśnie taką rolę zaczęło pełnić, a infiltracja skrajnych sił politycznych w województwie lubelskim zdecydowanie się nasiliła. Odnotowywały to niemal wszystkie sprawozdania instytucji cywilnych i wojskowych. Relacjonując sytuację w Horyszowie Polskim, TRZW w Zamościu informowało:

Ludność prawosławna tej wsi skupiła się całkowicie przy nacjonalistycznych hasłach ukraińskich i przez prowadzoną na miejscu przez miejscowych i przyjezdnych działaczy uodporniła się przeciwko wszelkim wpływom rewindykacyjnym. Postawa tej ludności jest zdecydowanie negatywna w stosunku do haseł polskich, że wszystkie stosowane metody oddziaływania zawodzą. [- - ] przywódcy jej zastosowali metody konspiracyjnej agitacji antypolskiej, przy równoczesnym stwarzaniu na zewnątrz pozorów pełnej lojalności państwowej, a nawet twórczej działalności na rzecz Państwa ${ }^{105}$.

W takiej atmosferze w sierpniu 1938 r. doszło w Horyszowie Polskim do podpalenia zabudowań miejscowego podsołtysa wyznania prawosławnego, który rozpoczął agitację na rzecz konwersji na katolicyzm ${ }^{106}$.

Jak wspomniano wcześniej, wskutek działań wojska i administracji cywilnej następowała szybka integracja społeczeństwa prawosławnego oraz ożywienie życia religijnego. W jednym ze sprawozdań z powiatu chełmskiego odnotowano: „,zaznaczyła się zwiększona gorliwość religijna, a mianowicie chłopi biorą udział w uroczystościach cerkiewnych, dojeżdżając do cerkwi z najdalszych odległości”. W Dorohusku natomiast wyznawcy prawosławia, protestując przeciwko wygłaszaniu kazań w języku polskim, przekraczali Bug, by po stronie wołyńskiej uczestniczyć w nabożeństwach z kazaniami w języku ukraińskim ${ }^{107}$. Wojnowski, wnikliwy obserwator stosunków na Wołyniu i w powiecie chełmskim, uczestnicząc w nabożeństwie

105 CAW, 3 DPL, sygn. I,313,3,2, Pismo Zarządu Koła Powiatowego TRZW w Zamościu do płk. M. Turkowskiego, 11 IV 1939, b.pag.

${ }^{106}$ Ibidem, mjr J. Podziemski, Sprawozdanie z terenu gminy Nowa Osada, pow. zamojski, 17 X 1938, b.pag.

${ }^{107}$ CAW, Oddz. II Szt. Gł., Sam. Ref. Inf. DOK II, sygn. 1772,89,99, Meldunek sytuacyjny tygodniowy 7 Pułku Piechoty Legionów do dow. 3 DPL, 17 X 1938, b.pag.; ibidem, Pismo kierownika akcji koordynacyjnej na pow. Chełm, Luboml, Krasnystaw do dow. 3 DPL, 18 III 1939, b.pag. 
w cerkwi w Wojsławicach, zwrócił uwagę, że kazanie utrzymane było w duchu pierwszych chrześcijan cierpiących za wiarę ${ }^{108}$. Taka atmosfera utrzymywała się w wielu miejscowościach na Lubelszczyźnie.

Działania władz skutkowały niepożądanymi z punktu widzenia czynników państwowych zachowaniami mniejszości ukraińskiej. Przyśpieszenia nabierał proces ukrainizacji miejscowych wyznawców prawosławia, gdyż w optyce społeczeństwa ukraińskiego, a zwłaszcza jego elit, rozbiórki cerkwi i likwidacja nieetatowych parafii prawosławnych były dowodem na prześladowania narodowościowe mniejszości ukraińskiej. Wszystko to bardzo mocno rzutowało na sytuację społeczną w regionie. Atmosfera wzajemnej nieufności, a nawet wrogości skutkowała zrywaniem dotychczasowych więzi sąsiedzkich, co wyrażało się brakiem kontaktów towarzyskich, typowej w środowiskach wiejskich wzajemnej pomocy w pracach polowych, wspierania ubogich drugiego wyznania itp. ${ }^{109} \mathrm{~W}$ świetle dokumentów wojskowych wiosną 1939 r. w niektórych regionach Chełmszczyzny i Podlasia Południowego mniejszość ukraińska zaczęła nawet organizować struktury samoobrony przeciw katolickim sąsiadom, co było szczególnie niebezpieczne z punktu widzenia bezpieczeństwa w ostatnich miesiącach pokoju. O zorganizowanych formach samoobrony ludności ukraińskiej mówił między innymi meldunek TRZW z powiatu hrubieszowskiego, posiadającego największy na Lubelszczyźnie odsetek ludności prawosławnej. Czytamy w nim: „Odbywają się ćwiczenia zbiórek i alarmów, służby wartowniczej oraz łączności z bronią w ręku. Jako broń używane są widły o jednym ostrzu na długim trzymetrowym drążku i kosy osadzone na sztorc. Nastroje są wysoce agresywne". Od jesieni 1938 r. w powiecie hrubieszowskim atmosfera stała się wyjątkowo napięta. We wsi Hołubie doszło nawet do zabójstwa dokonanego - zdaniem TRZW - właśnie przez owych ukraińskich wartowników na polskim żołnierzu. Udaremniony został natomiast napad na polską wieś Janki, organizowany przez mieszkańców okolicznych wsi ukraińskich. Nagminne były też przypadki wzajemnego wybijania sobie szyb czy niszczenia upraw ${ }^{110}$.

Akcja rewindykacyjno-konwersyjna, która miała doprowadzić do całkowitego spolonizowania wschodnich i południowych powiatów Lubelszczyzny, paradoksalnie ugruntowywała przekonanie o integralnych związkach tego obszaru z resztą ziem ukraińskich. Działający tu agitatorzy

108 CAW, Oddz. II Szt. Gł., Sam. Ref. Inf. DOK II, sygn. 272/13, J. Wojnowski, Reportaże z powiatów: kowelskiego, łuckiego, horochowskiego, włodzimierskiego i chełmskiego, 10 VII-25 VIII 1938, b.pag.

${ }^{109}$ K. Grzesiak, op. cit., s. 230.

${ }^{110}$ CAW, Oddz. II Szt. Gł., Sam. Ref. Inf. DOK II, sygn. 1772,89,99, Pismo TRZW, Oddział w Hrubieszowie do dow. 3 DPL, 17 IV 1939, b.pag. 
często podkreślali, że „ziemia ukraińska jest tutaj, bo granica Ukrainy biegnie pod Zamościem i Chełmem"111. Co więcej, próba spolonizowania Chełmszczyzny i części Podlasia niebezpiecznie nadszarpnęła autorytet państwa polskiego w szerszym wymiarze, przynajmniej w odniesieniu do całego pogranicza polsko-ukraińskiego. Wśród mniejszości ukraińskiej powszechne stało się oczekiwanie na wybuch wojny, która położy kres istnienia znienawidzonego państwa polskiego: „Nas Polska gnębi, a jak będzie wojna, to Polskę pognębią”. Nadzieje na powstanie niepodległego państwa ukraińskiego powszechnie wiązano z Adolfem Hitle$\mathrm{rem}^{112}$. Wyczekiwaniu temu towarzyszyły przygotowania - czego nie ukrywano - do krwawego rozliczenia z Polakami, padały słowa: „idzie na rżnięcie Lachów, którymi będzie się dekorować drzewa"113.

Zastanawiająca w tym wszystkim jest sekwencja wydarzeń. Od października 1937 r. do końca zimy następnego roku trwała akcja rewindykacji wyznaniowych w województwie wołyńskim, prowadzona również $z$ udziałem Komitetu Koordynacyjnego przy DOK II. Poza odwołaniem krytykowanego przez armię wojewody Henryka Józewskiego nie przyniosła ona jednak zakładanych rezultatów, przeciwnie - nasiliła antagonizmy narodowościowe. Jeżeli więc Wołyń miał być poligonem doświadczalnym dla tego rodzaju działań na innych obszarach, to zebrane doświadczenia raczej powinny skłaniać do poniechania tego rodzaju planów. Tak się jednak nie stało. Ponad rok później rozpoczęto na szerszą skalę akcję konwersyjną na Chełmszczyźnie i Podlasiu Południowym, która zakończyła się w podobny sposób. Być może lubelski Okręg Korpusu liczył, że ze względu na znacznie niższy odsetek ludności prawosławnej i silniejsze wpływy polskie w województwie lubelskim będzie ona miała tu większe szanse powodzenia. Ostatecznie jednak skończyła się tym samym, czyli gwałtownym wzrostem zagrożenia irredentą ukraińską.

111 Ibidem, Pismo kierownika akcji koordynacyjnej do dow. 3 DPL, 5 X 1938, b.pag.

112 Ibidem; CAW, Oddz. II Szt. Gł., Sam. Ref. Inf. DOK II, sygn. 1772,89,99, Pismo komendanta powiatowego PW i WF w Tomaszowie Lubelskim do dow. 3 DPL, 20 I 1939, b.pag.; ibidem, Pismo TRZW, koło powiatowe w Biłgoraju do kierownika akcji koordynacyjnej, 2 IV 1939, b.pag.

${ }^{113}$ Ibidem, Pismo TRZW, koło Tomaszów Lubelski do dow. 3 DPL, 8 IV 1939, b.pag.; ibidem, Pismo kierownika akcji koordynacyjnej do dow. 3 DPL, 5 X 1938, b.pag. 


\section{Participation of the Army in the Revindication-Polonisation Campaign Conducted in the Eastern and Southern Counties of the Voivodeship of Lublin in 1937-1939}

The revindication-Polonisation campaign carried out in the regions of Chełm and Southern Podlasie was a fragment of the national policy pursued by the Polish state while dealing with the Ukrainian national minority in the second half of the 1930s. An essential part of the programme's construction and implementation was played by the armed forces. The fundamental target of the policy in question involved improving the security of the Polish state in the conditions of a growing external threat and the rise of irredentist attitudes among the Ukrainians. Foremost undertakings included the marginalisation or total elimination of problems produced by the political activity of the Ukrainian minority in the eastern and southern counties of the voivodeship of Lublin. According to the premises formulated by the Army the line of the river Bug was to delineate the western boundary of the impact of the Ukrainian minority in Poland, which, as a consequence, denoted the need to Polonise the above-mentioned counties, mixed both as regards creed and nationality.

The ensuing operations aimed at radically restricting the influence of the Russian Orthodox Church in the titular region by assuming a priori that it propagated Ukrainian national tendencies. The campaign conducted by the administrative authorities and the $2^{\text {nd }}$ Corps District Command consisted of liquidating Russian Orthodox parishes unrecognised by the Polish authorities together with all associated sacral objects, ensuring the Polish population and converts to Roman Catholicism a privileged position in economic and social domains, and expanding Polish cultural institutions.

The revindication-conversion campaign intent on a total Polonisation of this part of the region of Lublin ultimately yielded reverse effects and confirmed a conviction about links with other Ukrainian lands. The Ukrainian minority now collectively awaited an outbreak of a war that would put an end to the existence of the abhorred Polish state.

Translated by Aleksandra Rodzińska-Chojnowska 